\title{
MICROTAPHOFACIES ANALYSIS OF LOWER OLIGOCENE TURBID-WATER CORAL ASSEMBLAGES
}

\author{
GIULIA SILVESTRI, ${ }^{*}$ FRANCESCA R. BOSELLINI, ${ }^{1}$ and JAMES H. NEBELSICK ${ }^{2}$ \\ ${ }^{1}$ Università di Modena e Reggio Emilia, Dipartimento di Scienze della Terra, Piazza S. Eufemia 19, 41121 Modena, Italy, giulia. silvestri@unimore.it, \\ francesca.bosellini@unimore.it; ${ }^{2}$ Universität Tübingen, Institut für Geowissenschaften, Sigwartstrasse 10,D-72076, Germany, nebelsick@uni-tuebingen.de
}

\begin{abstract}
The presence, distribution, and preservation of coral-rich facies in the lower Oligocene Gornji Grad Beds of Slovenia are analyzed using a microtaphofacies approach. This method allows taphonomic signatures to be recognized in thin section along with the presence of coral specimens and growth forms within and between stratigraphic logs. Coral-dominated limestones within the Gornji Grad Beds are represented by rudstones in a packstone-wackestone matrix. The conditions are generally reconstructed as turbid water due to the prevalence of muddy carbonate matrix, which also leads to excellently preserved morphological features in thin section. These beds represent a reference area for the study of Paleogene corals, especially during the Oligocene, a key phase of reef development during the Cenozoic. This study also contributes to the characterization of fossil reefs in turbid-water environments. The evaluated coral fauna is dominated by delicate-branching Stylophora and Acropora, although thickly branching (Actinacis, Goniopora), phaceloid (Caulastrea), and massive forms (Alveopora, Astreopora, Antiguastrea) also occur. Assessed taphonomic signatures include fragmentation, abrasion, bioerosion, and encrustation. Three types of bioerosion traces are distinguished (Entobia, Gastrochoenolites, Trypanites). Encrustation includes both thin crusts and complex multi-taxon sequences dominated by coralline algae. Five microtaphofacies are distinguished based on variation of taphonomic signatures, taxonomic composition, and growth forms. Differences in microtaphofacies are interpreted with respect to turbidity, sediment accumulation, and water turbulence; both parautochthonous and allochthonous deposits are reconstructed. A depositional model based on the distribution of microtaphofacies in the studied sections shows a succession of coral communities with different colonization strategies reflecting generally high stress levels.
\end{abstract}

\section{INTRODUCTION}

Coral reef frameworks and coral rubble are very common facies in the geological record. Studies from modern coral reefs, however, clearly reveal that taphonomic processes play a major role in determining the characteristics of both coral framework and rubble preservation (e.g., Pandolfi and Greenstein, 1997; Greenstein and Pandolfi, 2003; Blanchon and Perry, 2004; Perry and Smithers, 2006). These taphonomic processes can either act as constructive (e.g., by encrustation or marine cementation) or destructive (e.g., bioerosion and physical disruption) agents (Hutchings, 1986; Scoffin, 1992; Greenstein, 2007; Perry and Hepburn, 2008), with the latter commonly being responsible for the formation of abundant skeletal debris, as recognized, for example, from cores through modern reefs (Hubbard et al., 1990, 2001). This is also the case in the fossil record, where coral rubble is often a dominant facies (coral floatstones and rudstones) of shallow-water carbonate systems, while in situ reef frameworks are quite rare (e.g., Flügel, 2004). Despite their relevance, however,

* Corresponding author.

Copyright $\odot$ 2011, SEPM (Society for Sedimentary Geology) taphonomic processes as possible paleoenvironmental indicators of ancient coral frameworks and rubble deposits are rarely investigated.

Studies of reefs in present-day, turbid, nearshore environments have shown that the internal depositional fabrics of these reefs contain a particularly high proportion of coral rubble (Perry, 2005; Perry and Smithers, 2006) exhibiting a distinct suite of taphonomic signatures. In these settings, coral clasts are characterized by limited encrustation, variable levels of bioerosion, poorly developed marine cements, and a low degree of porosity due to prevalent fine-grained sediments. The presence, intensity, and temporal sequence of these processes, such as the relative abundance of key encrusters and/or bioeroders, vary according to the types of skeletons and growth forms present, as well as ambient environmental parameters such as depth, wave energy, light, turbidity, and nutrient availability (Pandolfi and Greenstein, 1997; Greenstein and Pandolfi, 2003; Perry and Hepburn, 2008). Generally, the longer the surface residence time of a skeletal component before final burial, the more diagnostic taphonomic signatures can be present (Perry and Hepburn, 2008). As a consequence, according to Nebelsick and Kiene (1997), the study of poorly preserved coral fragments due to high taphonomic alteration can significantly contribute to the reconstructions of reef environments.

In the literature of fossil coral reefs, taphonomy is basically perceived through studies concerning bioerosion, especially macroboring, and its role within processes of reef evolution and reef demise (Hallock, 1988; Vogel, 1993; Wood, 1993; Edinger and Risk, 1994; Perry, 1996; Bertling, 2000; Perry and Bertling, 2000). Detailed studies dealing with the recognition of coral taphofacies based on different taphonomic signatures are lacking. One method to study the taphonomy of coralbearing facies in the fossil record is to apply a microtaphofacies approach (Brachert et al., 1998, Nebelsick et al., 2011a). This method entails describing and eventually quantifying taphonomic signatures recognized in thin section and permits the taphonomy of components to be studied in indurated carbonates where little information can be gained from isolated three-dimensionally preserved fossils. Applying microtaphofacies analysis to regularly spaced thin-section series makes it possible to compare taphonomic development within and between stratigraphic logs. Taphonomic signatures such as encrustation and bioerosion sequences can be followed in great detail and the temporal sequence of events can thus be reconstructed. Many aspects of taphonomic observations of carbonates in thin section are inherent to microfacies analysis (see numerous examples in Flügel, 2004) and have been discussed by several authors (e.g., Sanders, 1999, 2003; Olóriz et al., 2004; Sanders and Krainer, 2005; Reolid and Gaillard, 2007; Reolid et al., 2007).

Studies on both recent and fossil coral communities have also shown that corals and coral reefs can thrive in episodically or permanently turbid water conditions. These environments differ from those of shallow-water, clear, oligotrophic settings (Hallock and Schlager, 1986; Schlager, 2000, 2003; Hallock, 2005) with respect to the various controlling ecological parameters such as light, turbidity, salinity, sedimentation rate, and nutrient conditions, as well as the resulting faunal composition. Turbid-water settings have been a continuously 
available habitat for corals in the past (Potts and Jacobs, 2000) and are characterized by well-developed coral growth (Woolfe and Larcombe, 1999; Perry, 2005). Many coral bioconstructions in the fossil record are, in fact, associated with marly and mixed carbonate-siliciclastic sediments (Sanders and Baron-Szabo, 2005). There are few studies, however, concerning the composition, structure, and depositional relationship of corals in ancient turbid-water habitats, especially in the Cenozoic (Braga et al., 1990; Wilson, 2005; Lokier et al., 2009; Klaus et al., 2011; Morsilli et al., 2011).

The main purpose of this study is to analyze the presence, distribution, and preservation of coral-rich facies in the lower Oligocene, Gornji Grad Beds of Slovenia based on thin-section analysis and recognition of microtaphofacies (MTFs). Numerous thin sections allow the corals and their preservational features to be analyzed and interpreted in order to provide a more detailed characterization of fossil reefs in turbid-water settings, specifically within the Oligocene reef window. This was a time of reef development and high coral diversity (Frost, 1977; Budd, 2000; Perrin, 2002; Bosellini and Perrin, 2008; Johnson et al., 2008) when coral communities not only successfully colonized open sea margins of carbonate platforms, but also thrived in turbid environments such as delta and nearshore depositional settings.

\section{GEOLOGIC SETTING}

The lower Oligocene Gornji Grad Beds in Slovenia (Fig. 1) represent one of the most significant coral-bearing units for the early Oligocene (Rupelian) of the northwestern Tethys. Corals from the Gornji Grad Beds (named Oberburg in the older literature) are described in the classic systematic study of Reuss (1864). This fauna was subsequently revised in part by Barta-Calmus (1973) based on the very incomplete Reuss collection deposited at the Natural History Museum in Vienna, Austria, and on other collections at the Museum of the Ivan Rakovec Institute of Palaeontology of Ljubljana, Slovenia. Recently, the Gornji Grad Beds have been the subject of several studies on specific components, especially coralline algae (Bassi and Nebelsick, 2000; Nebelsick and Bassi, 2000) and facies relationships (Nebelsick et al., 2000; Schmiedl et al., 2002), but no modern studies have been completed on the corals or coral facies in particular. Corals within the Gornji Grad Beds are contained mainly within indurated rudstone carbonates with some isolated colonies observed in intercalated marly intervals (Nebelsick et al., 2000).

The transgressive Paleogene succession to which the Gornji Grad Beds belong (Fig. 1) is initiated by the limno-fluviatile Basal unit consisting of conglomerates, sandstones, and marls, formally assigned to the Okonina conglomerates (Hemleben, 1964; Cimerman, 1979). The thickness of this unit reaches up to $400 \mathrm{~m}$ and includes charophytes that indicate a late Eocene-early Oligocene age (Schmiedl et al., 2002). The Basal unit can also be represented by $50-70 \mathrm{~m}$ of coarse sandstones and conglomerates. The Gornji Grad Beds overlie not only this Basal unit (in the southern part of the study area), but can also follow Eocene limestones (to the north) or directly transgress over Triassic limestones (Nebelsick et al., 2000).

The Gornji Grad Beds themselves consist of a 5-30-m-thick succession of brackish to marine marls, sandstones, and marine carbonates. Marine conditions are indicated by the appearance of marine benthic foraminifera (Hemleben, 1964; Schmiedl et al., 2002). The presence of Nummulites fichteli and $N$. germanicus as well as Halykardia maxima and "Peneroplis armorica" (Drobne et al., 1985; Nebelsick et al., 2000) dates the Gornji Grad Beds as early Oligocene corresponding to Biozone SB21 (Cahuzac and Poignant, 1997). The Gornji Grad Beds are followed by the $\sim 170-270 \mathrm{~m}$ marls of the Tegel unit (Schmiedl et al., 2002) deposited during the late Oligocene (nannoplankton zones NP23-NP24; Jelen et al., 1980; Bricl and Pavšič, 1991). These sediments are capped by the late Oligocene-early Miocene volcaniclastic Tuffite unit (Hanfland et al., 2004).

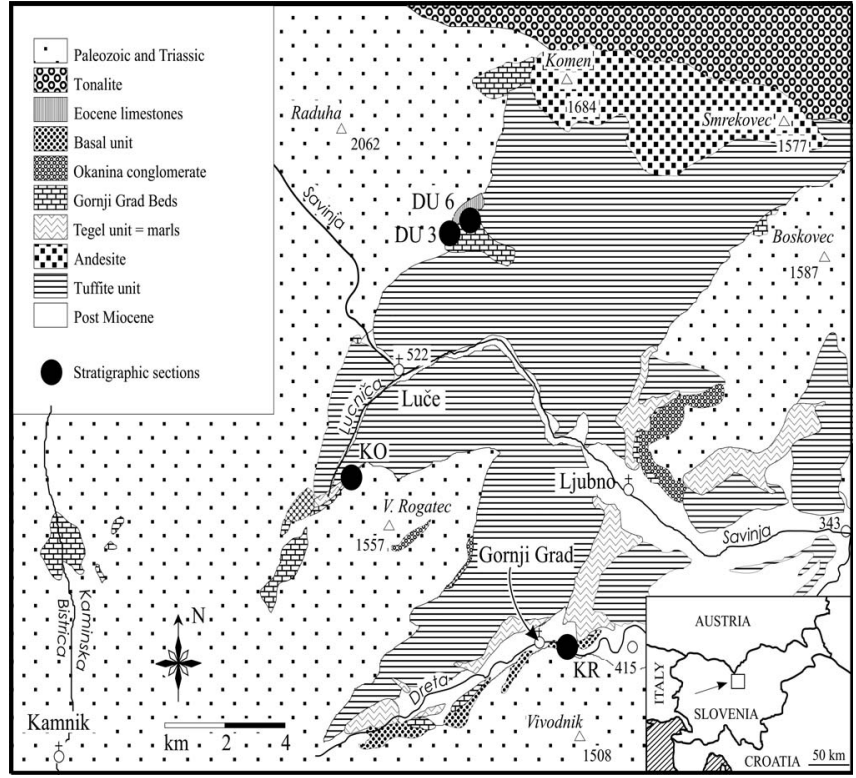

FIGURE 1-Location of the study area with geological map. The four selected localities are indicated: Krznar (KR), Korenovec (KO), Dupeljnik-3 (DU3), and Dupeljnik-6 (DU6) (modified from Nebelsick et al., 2000).

Microfacies analysis of the Gornji Grad Beds (Nebelsick et al., 2000) shows carbonates dominated by poorly sorted rudstones with packstone-wackestone matrix. Subordinate packstones and grainstones are also present. Coralline algae are the best-studied components of the Gornji Grad Beds with eleven species belonging to nine genera present (Bassi and Nebelsick, 2000; Nebelsick and Bassi, 2000; Nebelsick et al., 2000). Corals are common within the limestones as well as isolated finds within marls. Further components are smaller benthic foraminifera, larger benthic foraminifera, encrusting foraminifera such as Haddonia, and bivalves. Subordinate components are bryozoans, echinoderms, gastropods, serpulids, thecideid brachiopods, and dasycladalean green algae. Carbonate facies were distinguished using multivariate statistical treatment of point-counting results of thin sections as well as general fabric analysis. The following facies were discerned: (1) nummulitic, (2) bivalve, (3) foraminiferal-coralline algal, (4) grainstone, (5) coralline algal, (6) coralline algal-coral, and (7) coral facies. These facies were interpreted with respect to substrate characteristics, water turbulence, sediment input, and light (Nebelsick et al., 2000).

All of these facies, except for the grainstone facies, are characterized by a high content of carbonate muddy matrix. The coral facies generally shows rudstones in packstone-wackestone matrix. Corals dominate this facies (on average $60 \%$ of the component contribution) together with subordinate encrusting coralline algae. Other rare components are small and larger foraminifera, bivalves, and echinoderms, as well as foraminifera and bryozoans included within encrustation sequences.

\section{MATERIAL AND METHODS}

This study is based in part on the stratigraphic sections used for facies reconstructions (Nebelsick et al., 2000) and for the study of coralline algae (Bassi and Nebelsick, 2000; Nebelsick and Bassi, 2000; Nebelsick et al., 2000). Four stratigraphic sections where corals dominate are investigated in more detail: Krznar (KR), Korenovec (KO), Dupeljnik-3 (DU3), and Dupeljnik-6 (DU6) (Fig. 1).

Microtaphofacies analysis has been performed using 42 standard (5 $\times 5 \mathrm{~cm})$ and 25 large $(\sim 8 \times 10 \mathrm{~cm})$ thin sections cut perpendicular to the bedding plane. A detailed microtaphofacies analysis is possible due to the exceptionally well-preserved features visible in thin section. Rock 
textures were named following Dunham (1962). The textural classification of Embry and Klovan (1971) was used allowing for a general component and matrix description. The coral fauna was examined with respect to taxonomic composition (at the generic level), growth forms, and taphonomy. The semiquantitative evaluation of coral presence and growth forms used three categories: (1) not present, (2) rare, and (3) common (Figs. 4-7).

Eight coral genera were identified: Stylophora, Acropora, Astreopora, Actinacis, Goniopora, Alveopora, Caulastrea, and Antiguastrea (Fig. 2). Unidentified corals, due to the lack of distinguishing characters or the effects of high fragmentation rates and/or diagenetic processes, were also considered. Nevertheless, these do not exceed an average of $30 \%-$ $40 \%$ within the total number of thin sections. Organisms belonging to the class Hydrozoa that could not be assigned to a lower taxonomic level have been considered as well.

Four different coral growth forms were distinguished: branching, thick-branched, phaceloid, and massive. Branching morphotypes consist of finely arborescent coral colonies having corallites distributed all around the branches. Thick-branched corals are usually nonarborescent, with a digitate to columnar-like shape, and also have corallites all around the branches. Phaceloid forms contain differentially spaced single branches, each corresponding to a single corallite. Corallites can be monocentric or bi- to tricentric. The term massive is used in a broad sense to indicate non-ramose (branching or phaceloid) morphologies ranging from domal to globose or possibly slightly tabular forms.

Taphonomic processes can be differentiated into: (1) processes occurring before final burial (the subject of this paper), and (2) postdepositional features including diagenesis, compaction and resulting pressure solution. Diagenesis leads to the leaching of the primary aragonitic skeletons of the corals and their replacement by calcite. Distinguished taphonomic signatures are fragmentation, abrasion, encrustation, and bioerosion. Their degree of incidence is semiquantitatively estimated according to three categories, namely (1) low, (2) moderate or (3) high (Figs. 4-7).

Fragmentation (Fig. 3A) cuts across morphological features. Facies consisting of coral floatstones-rudstones, especially if dominated by delicate-branching growth forms as in the present study, obviously show a certain degree of fragmentation. Low rates are scored if fragmentation is restricted to delicate-branching corals, and high rates when massive coral growth forms are fragmented.

Abrasion (Fig. 3B) is clear when surface morphological features such as the wall structures have been removed; the loss of these features leads to a reduction in the diameter of the corals. Diameter can only be assessed for branching or phaceloid corals cut perpendicular to their growth orientation.

Encrustation (Fig. 3C) occurs by a variety of organisms dominated by various coralline algae and encrusting foraminifera such as Haddonia. Unidentified species of encrusting gypsinid, acervulinid, and planorbulinid foraminifera are rare, along with thecideid brachiopods and bryozoans (Bassi and Nebelsick, 2000; Nebelsick and Bassi, 2000; Nebelsick et al., 2000, 2011b). Occasionally, complex, multi-taxon encrustation sequences are present.

Bioerosion (Fig. 3D) is usually distinguished into microboring and macroboring (Perry and Hepburn, 2008 and references therein). Microboring results from the activity of photosynthetic cyanobacteria, chlorophytes, and rhodophytes, as well as heterotrophic fungi and bacteria, producing boreholes ranging from 1-100 $\mu \mathrm{m}$. Organisms responsible for macroboring include sponges, polychaete and sipunculid worms, bivalves, and cirripeds. Only bioerosion falling within the macroboring size range is analyzed in this paper as these boreholes can be easily distinguished and identified in thin section. Bioerosion is recognizable through sediment-filled holes in the calyx; the bioeroding organisms themselves are rarely preserved. Three types of bioerosion traces are identified:
1. Subrounded to rounded chambers, in part interconnected, referred to the ichnogenus Entobia resulting most likely from boring clionid sponges (Bromley and D’Alessandro, 1984, 1989).

2. Large round holes, referred to the ichnogenus Gastrochoenolites, probably resulting from boring bivalves such as Lithophaga (Kelly and Bromley, 1984; Scott, 1988).

3. Short and narrow small borings, rounded in cross section, referred to the ichnogenus Trypanites probably produced by polychaete and sipunculid worms (Bromley, 1972).

\section{RESULTS: STRATIGRAPHIC SECTIONS}

\section{Krznar Section (KR)}

The Krznar section (Fig. 4) can be correlated to the type locality of Reuss's (1864) collection (C. Hemleben, personal communication, 1994). The section begins with $\sim 6 \mathrm{~m}$ of poorly exposed sandstones attributed to the bivalve facies that contain only rare, very small unidentified coral fragments. The top of the section consists of $\sim 2$ meters of weakly consolidated coralline algal-coral rudstones separated by thin marly layers, which can be rich in isolated corals dominated by thin-branched Stylophora and subordinate Acropora. The beds become richer in coralline algae and corals before the onset of the marls of the Tegel unit.

The base of the coral facies consists of a rudstone with a wackestone (locally packstone) matrix. Both scleractinian corals and hydrozoans are present. Fragments of phaceloid Caulastrea-like corals dominate, together with fragments of branching Stylophora and thick-branched Actinacis; a few fragments of Astreopora occur as well. Coralline algae are abundant as isolated thalli and sometimes as encrusting forms. Toward the top of the section, the coral facies is represented by a welldefined, 60-cm-thick layer with abundant fragments of branching corals lying parallel to bedding. Phaceloid corals such as Caulastrea are dominant, together with Stylophora, Alveopora, Actinacis, and some acroporiids (Astreopora or Acropora) as well as isolated Antiguastrea.

\section{Korenovec Section (KO)}

As illustrated by Nebelsick et al. (2000) and Nebelsick and Bassi (2000), the 6-m-thick Korenovec section shows a variety of facies (Fig. 5). Coral remains, although unidentifiable at lower taxonomic level because of fragmentation and abrasion, are present as secondary components in the bivalve and grainstone facies. The base of the coral facies consists of rudstones with a wackestone-packstone matrix. Fragments of Acropora are dominant, together with abundant hydrozoans; fragments of Caulastrea are subordinate. Some fragments of Astreopora also occur. Associated fauna consists of miliolids, and fragments of bivalves and isolated coralline algal thalli. Corals become highly fragmented and difficult to recognize toward the top of the coral facies. Phaceloid colonies dominate with common branching corals (including Acropora). Subordinate massive coral fragments also occur. Coral fragments are oriented parallel to bedding.

\section{Dupeljnik-3 Section (DU3)}

The Gornji Grad beds reach their major thickness in the Dupeljnik Valley and especially along the Dupeljnik-3 section (Fig. 6). The base of the section consists of upper Eocene orthophragminid limestones, followed by $\sim 30 \mathrm{~m}$ of partially sandy marls. Oligocene limestones consist of distinct beds with marly intercalations and a wide variety of facies (Nebelsick et al., 2000).

Corals are generally present throughout the section as important secondary components. Corals in the coralline algal-coral facies show abundant fragments of phaceloid (Caulastrea) and branching (Acropora) growth forms. Stylophora is present, but not common. Only few 

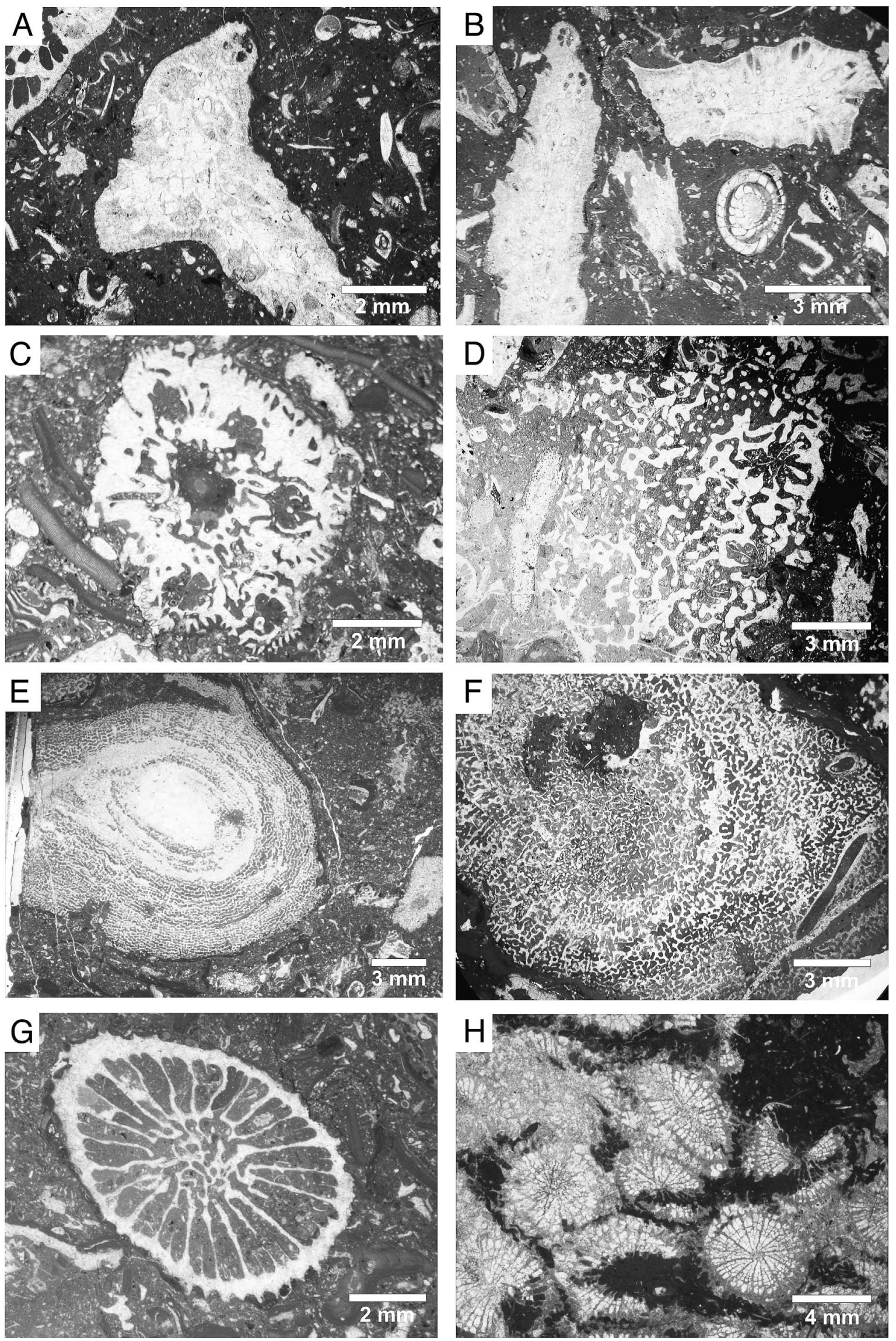

FIGURE 2-Main coral genera. A) Stylophora, SLO94-015. B) Stylophora, KO-21. C) Acropora, DU3-22. D) Astreopora, DU6-1. E) Actinacis, DU6-5. F) Goniopora, DU6-1. G) Caulastrea, DU3-22. H) Antiguastrea, SLO94-028 

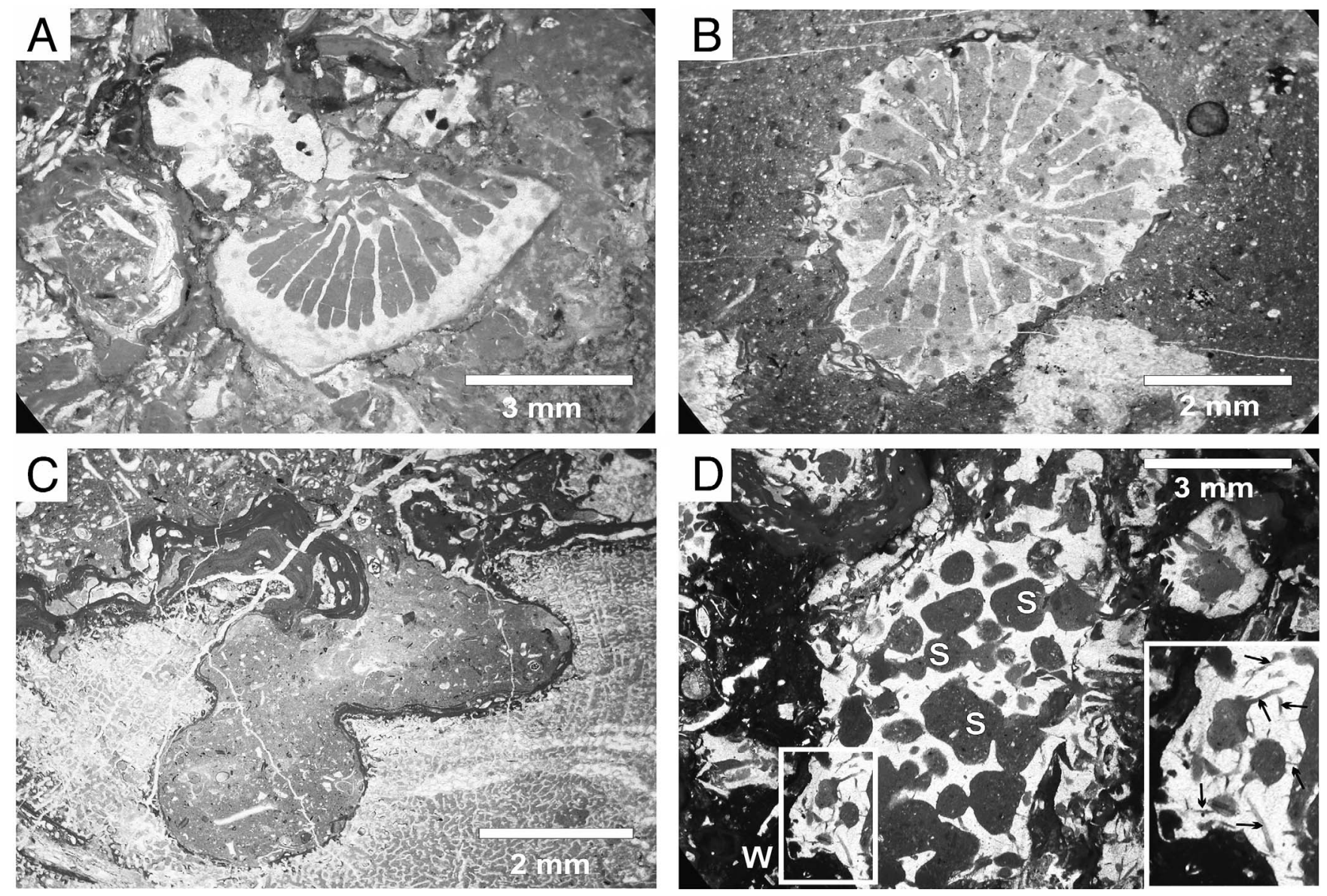

FIGURE 3-Primary taphonomic processes and signatures. A) Fragmentation, DU6-5. A fragmented calyx of a phaceloid-like coral showing incomplete wall structure, septa and columella. B) Abrasion of the outer wall of a calyx of a phaceloid-like coral, DU6-4. For comparison see the thicker wall in Fig. 3A. C) Encrustation: multi-taxon crust (coralline algae and foraminifera) on a previously bored coral (probably by Lithophaga), SLO94-027B. D) Bioerosion by clionid sponges (=S) and worms (=W; enlarged in inset, see arrows), DU6-5.

fragments of massive corals (Astreopora) and thick-branched corals (Actinacis-Goniopora) are present. In the middle part of the section corals are strongly fragmented and abraded, generally preventing lower taxonomic identification. Phaceloid growth forms are the most frequent, with branching (Acropora slightly dominates over Stylophora) and thick-branched forms subordinate; massive corals are absent. The grainstone facies at the top shows only few highly abraded coral fragments.

\section{Dupeljnik-6 Section (DU6)}

The Dupelnik-6 section (Fig. 7) follows stratigraphically above the Dupeljnik-3 section, is about $17 \mathrm{~m}$ thick, and consists of numerous limestone beds intercalated with marls. The limestones are completely dominated by the coral facies. Some graded bedding of components is present (DU6.2-6.4). The basal part of the section shows rudstones with a packstone-wackestone matrix. These beds are dominated by fragments of branching (mainly Acropora, with Stylophora subordinate and restricted to poorly preserved small fragments) and thick-branched corals (Goniopora dominant, with few Actinacis). Larger fragments of likely massive Astreopora also occur. Phaceloid corals (Caulastrea) are subordinate.

A relatively higher coral diversity is reached toward the middle part of the section. Acropora still dominates together with common Actinacis, Astreopora, and Goniopora. Caulastrea is also present, whereas Stylophora is rare. These beds also record the occurrence of a few massive faviids (Antiguastrea) and other smaller fragments. Branching hydrozoans are also present.

The top of the section is represented by rudstones with a packstone matrix rich in highly fragmented bioclasts. Diagenesis and compaction make taxonomic identification difficult with the exception of acroporiids (Acropora and Astreopora). Branching growth forms dominate, associated with phaceloid and massive forms. The clasts are distinctly oriented parallel to bedding.

\section{RESULTS: CORAL MICROTAPHOFACIES}

Five different coral MTFs are differentiated on the basis of dominant coral taxa, growth forms, and taphonomic signatures (fragmentation, abrasion, encrustation, and bioerosion) (Table 1). All sedimentary textures consist of rudstones with a wackestone to packstone matrix. MTFs 1, 2, 3, and 5 are dominated by corals and MTF 4 by coralline algae, with corals as significant secondary components. In general, MTFs have been recognized within only one stratigraphic section, with the exception of MTF 3 (KO and DU6 sections).

\section{Microtaphofacies 1}

Description (Figs. 8A-B).-Phaceloid, branching, and thick-branching corals occur together with hydrozoans in a wackestone matrix. Stylophora and Caulastrea dominate, but Actinacis is also present. 


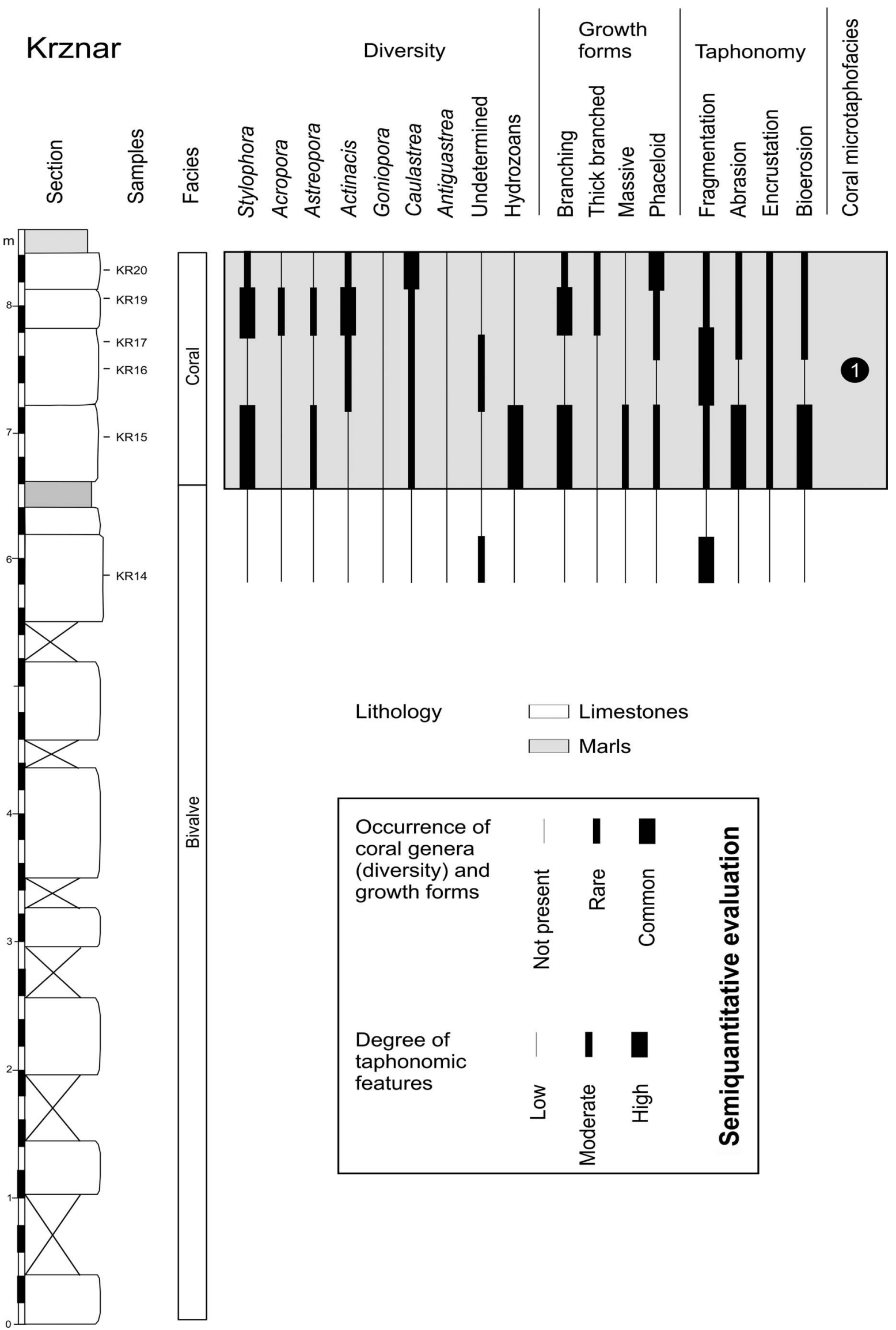

FIGURE 4-The Krznar section (KR) with semi-quantitative evaluation of coral diversity, growth forms and incidence of primary taphonomic processes. 


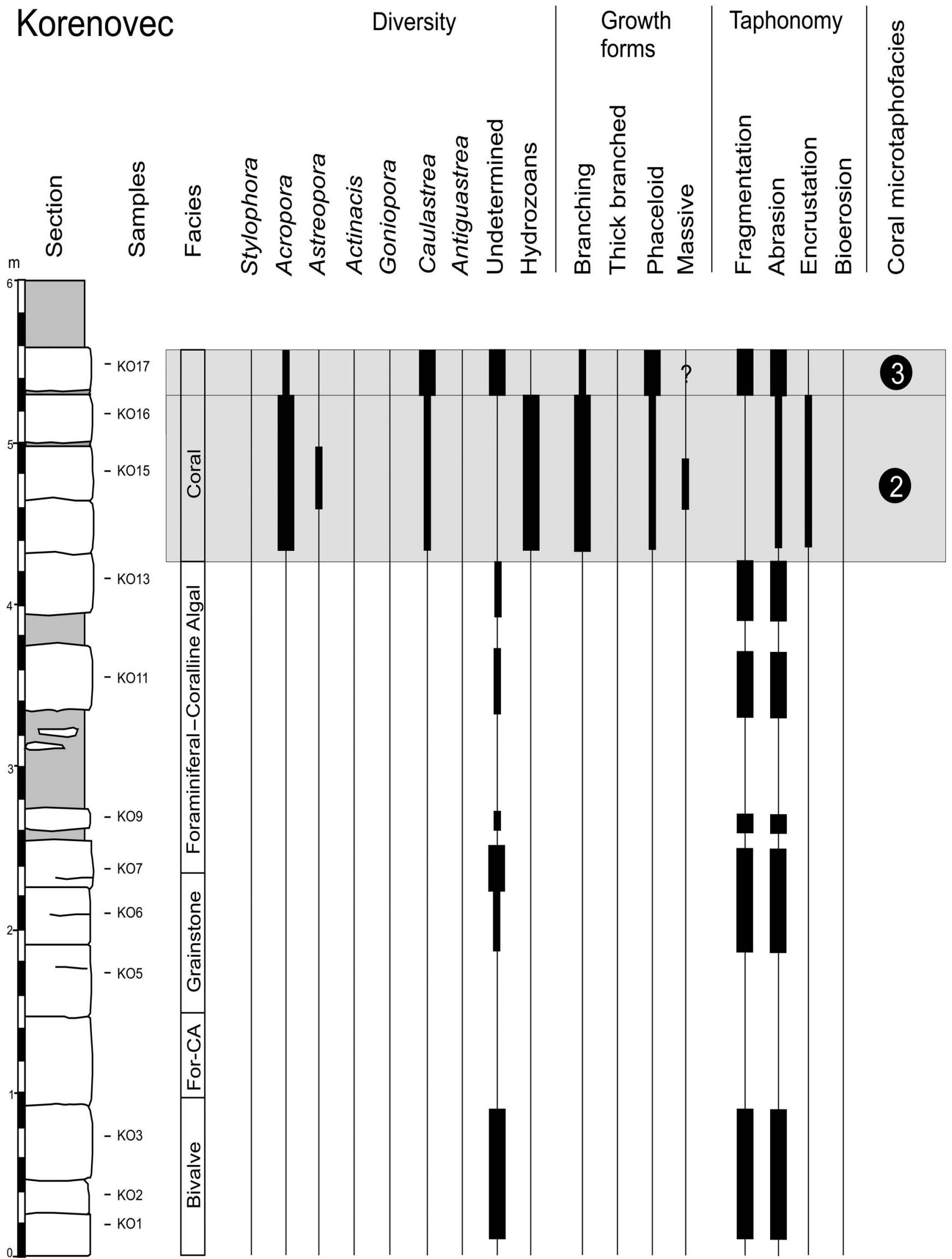

FIGURE 5-The Korenovec section (KO) with semi-quantitative evaluation of coral diversity, growth forms and incidence of primary taphonomic processes. See Fig. 4 for legend. 


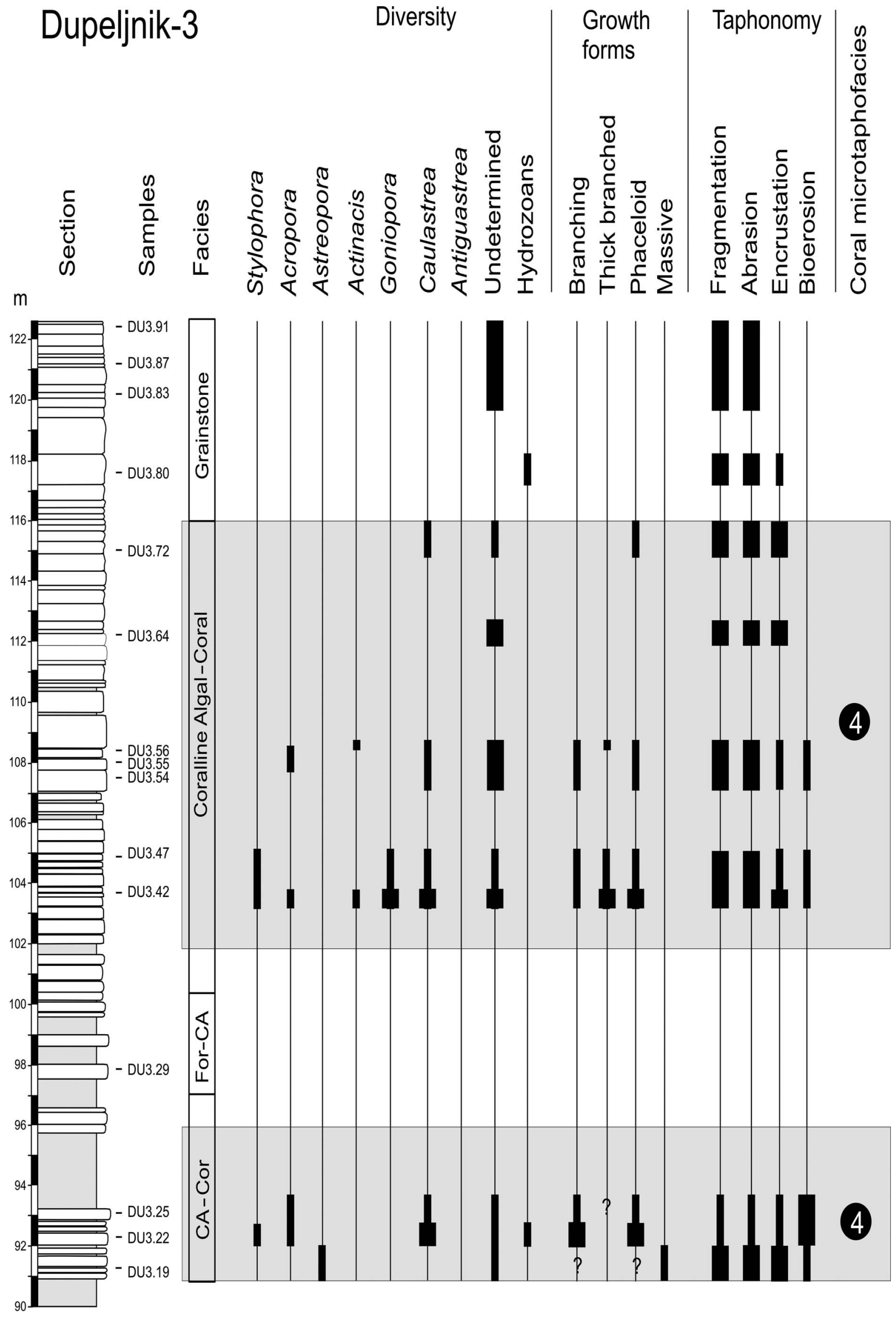

FIGURE 6-The Dupeljnik-3 section (DU3) with semi-quantitative evaluation of coral diversity, growth forms and incidence of primary taphonomic processes. See Fig. 4 for 

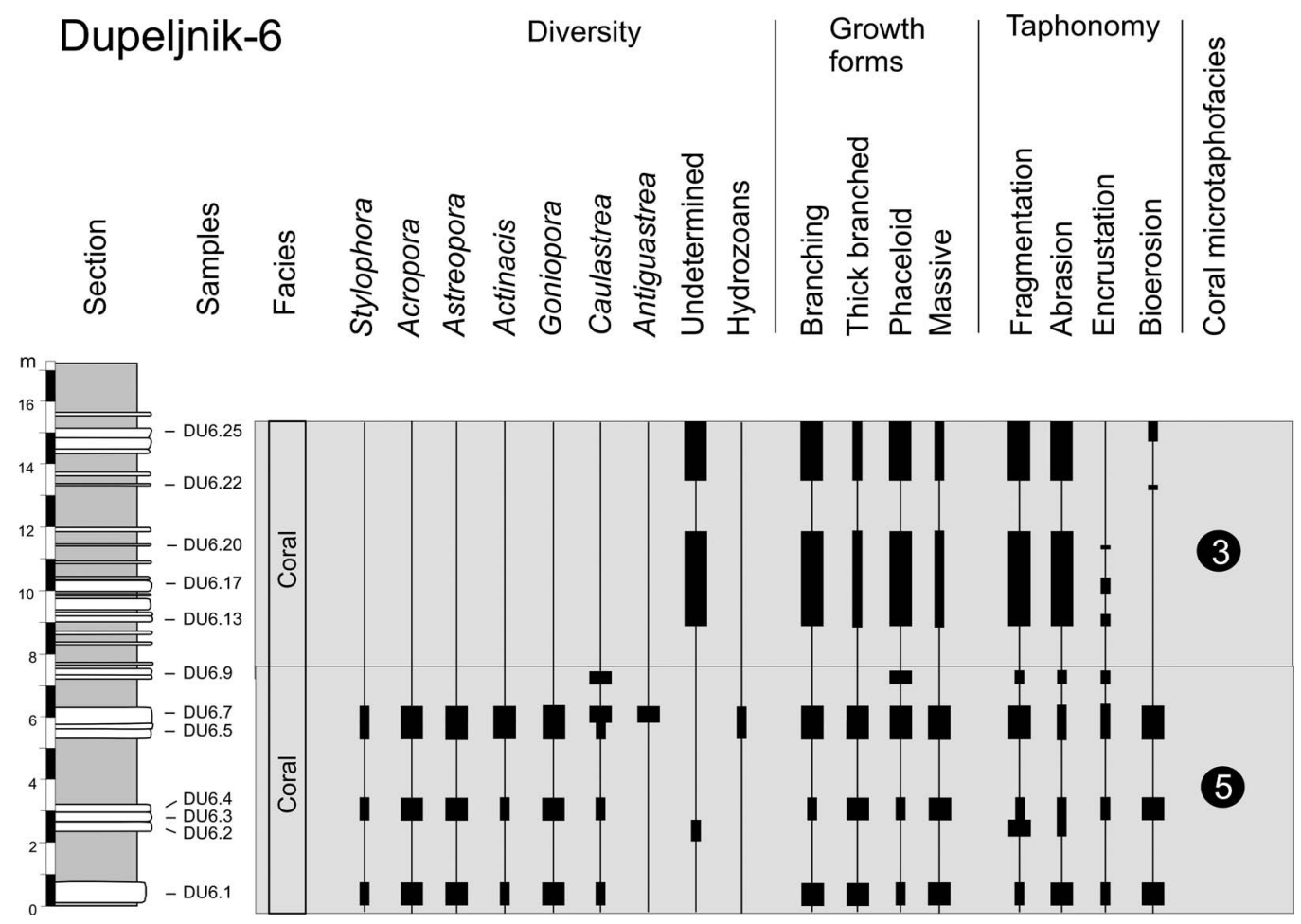

FIGURE 7-The Dupeljnik-6 section (DU6) with semi-quantitative evaluation of coral diversity, growth forms and incidence of primary taphonomic processes. See Fig. 4 for legend.

Fragmentation is scored as moderate due to the preservation of delicate, thinly branched growth forms (Fig. 8A) as well as fragmented thick-branched growth forms (Fig. 8B). Abrasion rate is high. Encrustation is sparsely present consisting of thin $(<1 \mathrm{~mm})$, laminar coralline algal crusts with subordinate encrusting foraminifera. No evidence of crusts fragmented together with corals is observed. Bioerosion is moderately present and slightly dominated by Gastrochoenolites. Some Entobia and Trypanites traces are present. Bioerosion traces are usually overlain by rare encrustations.

Distribution.-Restricted to top of the Krznar section (Fig. 4).

Interpretation.-The relatively diverse associated fauna and the stratigraphic position immediately above sandstones of the bivalve facies (Fig. 4) are interpreted to reflect a relatively proximal, sedimentinfluenced setting. The mud-dominated wackestone texture and the moderate occurrence of fragmentation, even on delicate growth forms, is consistent with a parautochthonous coral assemblage deposited in a relatively low-energy setting, occasionally affected by episodes of higher water energy. Encrustation is very variable even on single clasts as observed in present-day turbid nearshore environments (Perry, 2005). These features, according to Perry and Smithers (2006), may reflect a limited and/or variable surface residence time due to rapid sediment burial. A high supply of suspended organic matter from the coast, together with low water turbulence and sheltered conditions, could promote bioerosion. The stronger development of bioerosion with respect to encrustation may reflect the fact that the former process partially affected living corals. Bioerosion can weaken corals making them more vulnerable to breakage. Branching corals, with their reduced size and greater exposed surface areas, are especially prone to breakage even if depth of bioerosion is shallow (Pleydell and Jones, 1988). Corals were thus generally susceptible to higher fragmentation rates even during relatively low-energy conditions, with consequent production of a significant amount of coral rubble.

The low-diversity coral fauna is dominated by phaceloid, branching, and thick-branching growth forms. According to Stafford-Smith (1993), branching growth forms are by far the most effective with respect to sediment clearance by passive removal. Stylophora is considered a pioneer, fast-growing genus, common in a wide spectrum of stressed environments. Corals with phaceloid growth forms are also considered to flourish in sediment-influenced settings as they feed largely or entirely heterotrophically (Dryer and Logan, 1978). These growth forms represent adaptations to soft muddy substrates and to relative high sedimentation rates in low-hydrodynamic regimes (Dupraz and Strasser, 2002). Actinacis is also considered to be a pioneer, sediment-resistant genus (Frost, 1981), and its thick-branched growth form has been interpreted as an adaptation to quiet, muddy environments (Bosellini and Trevisani, 1992; Bosellini and Stemann, 1996).

\section{Microtaphofacies 2}

Description (Figs. 8C-D).-Branching corals (i.e., Acropora) and to a lesser extent phaceloid forms (i.e., Caulastrea) dominate, together with abundant delicately branched hydrozoans. Corals are embedded in a wackestone-packstone matrix; fragmentation is low and abrasion moderate. Encrustation is very variable and can be absent or homogenously developed around corals, usually as lumpy crusts up to $3 \mathrm{~mm}$ thick and composed of a multi-taxon assemblage including different coralline algal taxa, the calcareous alga Polystrata alba, bryozoans, and encrusting foraminifera (Haddonia). Bioerosion is low and restricted to a few Trypanites and Gastrochoenolites traces which are usually covered by encrustations (Fig. 8D). Some encrustations are fragmented together with their coral substrates (Fig. 8C).

Distribution.- - Restricted to the upper part of the Korenovec section (Fig. 5).

Interpretation.-Texture type, low fragmentation rates, and the dominance of delicately branched corals and hydrozoans reflect a very low hydrodynamic setting where corals were deposited nearly in situ. Given the inferred low-hydrodynamic regime, continuous reworking of coral rubble allowing for symmetrical growth of encrusters is unlikely. The presence of homogenous complex crusts thus suggests encrustation 
TABLE 1-Diagnostic features characterizing the five coral microtaphofacies.

\begin{tabular}{|c|c|c|c|c|c|c|c|c|c|c|c|c|c|c|}
\hline \multirow[b]{2}{*}{ MTF } & \multirow[b]{2}{*}{ Section } & \multirow[b]{2}{*}{ Texture } & \multirow[b]{2}{*}{ Dominant taxa } & \multirow{2}{*}{$\begin{array}{l}\text { Coral } \\
\text { growth } \\
\text { form }\end{array}$} & \multirow[b]{2}{*}{ Fragmentation } & \multirow[b]{2}{*}{ Abrasion } & \multicolumn{3}{|c|}{ Encrustation } & \multirow[b]{2}{*}{ Organisms } & \multicolumn{3}{|c|}{ Bioerosion } & \multirow{2}{*}{$\begin{array}{l}\text { Associated } \\
\text { fauna }\end{array}$} \\
\hline & & & & & & & Degree & Distribution & Shape & & Degree & Type & Organisms & \\
\hline 1 & KR & Wackestone & $\begin{array}{l}\text { Corals } \\
\text { (Caulastrea, } \\
\text { Stylophora, } \\
\text { Actinacis), } \\
\text { Hydrozoans }\end{array}$ & $\begin{array}{l}\text { Phaceloid, } \\
\text { branching, thick } \\
\text { branched }\end{array}$ & Moderate & High & Low & $\begin{array}{c}\text { Not } \\
\text { homogenous }\end{array}$ & $\begin{array}{l}\text { Thin, } \\
\text { laminar }\end{array}$ & $\begin{array}{l}\text { Coralline algae, } \\
\text { foraminifera } \\
\text { subordinate }\end{array}$ & Moderate & $\begin{array}{c}\text { Gastrochoenolites, } \\
\text { Entobia, } \\
\text { Trypanites }\end{array}$ & $\begin{array}{c}\text { Bivalves, } \\
\text { sponges, worms la }\end{array}$ & $\begin{array}{l}\text { Milioliids and } \\
\text { arger foraminifera }\end{array}$ \\
\hline 2 & KO & $\begin{array}{l}\text { Wackestone- } \\
\text { Packstone }\end{array}$ & $\begin{array}{c}\text { Corals } \\
\text { (Acropora), } \\
\text { Hydrozoans }\end{array}$ & Branching & Low & Moderate & Moderate & Homogenous & $\begin{array}{l}\text { Thick, } \\
\text { lumpy }\end{array}$ & $\begin{array}{c}\text { Multitaxon cor. } \\
\text { algae }+ \\
\text { foraminifera- } \\
\text { bryozoans }\end{array}$ & Low & Trypanites & Worms & Milioliids \\
\hline 3 & $\begin{array}{l}\text { KO (top) + } \\
\text { DU6 } \\
\text { (top) }\end{array}$ & Packstone & $\begin{array}{c}\text { Corals } \\
\text { (unidentified) }\end{array}$ & Phaceloid (?) & High & High & Low & - & - & - & Low & - & - & - \\
\hline 4 & DU3 & Packstone & $\begin{array}{l}\text { Coralline algae } \\
\text { (corals } \\
\text { subordinate) }\end{array}$ & Branching & High & High & High & Homogenous & $\begin{array}{l}\text { Thick, } \\
\text { lumpy }\end{array}$ & $\begin{array}{c}\text { Multitaxon cor. } \\
\text { algae }+ \\
\text { foraminifera- } \\
\text { bryozoans }\end{array}$ & Moderate & $\begin{array}{c}\text { Entobia, } \\
\text { Gastrochoenolites, } \\
\text { Trypanites }\end{array}$ & $\begin{array}{c}\text { Sponges, } \\
\text { bivalves, worms }\end{array}$ & $\begin{array}{l}\text { Mollusca, } \\
\text { Brachiopoda, } \\
\text { Echinoidea }\end{array}$ \\
\hline 5 & DU6 & $\begin{array}{l}\text { Wackestone- } \\
\text { Packstone }\end{array}$ & $\begin{array}{l}\text { Corals } \\
\text { (Acropora, } \\
\text { Goniopora, } \\
\text { massive) }\end{array}$ & $\begin{array}{l}\text { Thick } \\
\text { branched }\end{array}$ & High & Moderate & Moderate & Homogenous & $\begin{array}{l}\text { Variable } \\
\text { thickness, } \\
\text { lumpy usual }\end{array}$ & Coralline algae & High & $\begin{array}{l}\text { Gastrochoenolites, } \\
\text { Trypanites, } \\
\text { Entobia }\end{array}$ & $\begin{array}{c}\text { Bivalves, } \\
\text { worms, sponges }\end{array}$ & - \\
\hline
\end{tabular}

of living corals, also supported by the fact that fragmentation occurred after encrustation. The development of thick and complex encrustation sequences also suggests long-living corals, at least with respect to those of MTF 1. Well-developed encrustations around living corals could also strengthen the skeleton with respect to fragmentation and bioerosion. As turbidity is known to be disadvantageous for newly recruited calcareous encrusters (Perry and Smithers, 2006), this setting was probably relatively well lit and, in contrast to MTF 1 , was characterized by high sediment accumulation rates resulting in a dominance of branching growth forms.

\section{Microtaphofacies 3}

Description (Fig. 8E).-MTF 3 is totally dominated by strongly fragmented and abraded iso-oriented corals lying parallel to bedding and included within a packstone matrix. High fragmentation and abrasion preclude coral identification at lower taxonomic levels. The assemblage is dominated by phaceloid and/or branching growth forms with some massive corals. Bioerosion and encrustation rates are low, the latter with a few thin algal crusts. Fragmentation affects both corals and their encrustations.

Distribution.-Top of both the Korenovec (Fig. 5) and Dupeljnik-6 sections (Fig. 7).

Interpretation.-The iso-oriented coral fragments reflect an assemblage aligned by unidirectional currents. This orientation, together with the high rates of fragmentation and abrasion, suggests a relatively high rate of water agitation if not transport. Strong abrasion and fragmentation may have prohibited potential recognition of other taphonomic signatures such as encrustation and bioerosion. Higher accumulation rates did not promote post-depositional bioinfestation.

\section{Microtaphofacies 4}

Description (Fig. 8F).-The limestones of this MTF belong to the coralline algal-coral facies. Highly fragmented and abraded Acropora and Caulastrea dominate, but numerous corals are unrecognizable due to poor preservation. The associated sediment shows a packstone texture. Encrustation is very well developed and can be formed by multi-taxon assemblages dominated by coralline algae associated with encrusting foraminifera and bryozoans. Crusts are homogenously distributed around coral clasts, sometimes with lumpy growth forms. Most encrustations are developed around fragmented corals, although some crusts occur broken along with their substrates. Bioerosion rates (due to Entobia, Gastrochoenolites, and Trypanites) are very different, pervasive in some corals while lacking in others. Entobia preferentially affects Stylophora fragments. There is little evidence of traces broken by fragmentation. Boring traces usually occur underneath encrustations, but can also encompass both corals and crusts.

Distribution.-Restricted to the Dupeljnik-3 section (Fig. 6).

Interpretation.-The coralline algal-coral facies shows the highest diversity of coralline algae both in terms of taxa and growth forms (Nebelsick et al., 2000), reflecting a variety of substrate conditions. Highly reworked, non-autochthonous coral fragments most probably provided suitable substrates for the coralline algae. The packstone texture, locally grading into grainstones, is consistent with a relatively higher hydraulic regime than in the previous MTFs. Both transport and reworking were responsible for fragmentation and abrasion. The development of complex and thick encrustation sequences reflects an exposed setting characterized by relatively high water turbulence and low sedimentation rate leading to a relatively long surface residence time of coral remains.

\section{Microtaphofacies 5}

Description (Figs. 9A-C).-This MTF is represented by densely packed rudstones in a wackestone-packstone matrix. The coral fauna appears to be more diverse than in the other MTFs. Very common delicate-branching corals (mostly Acropora) are accompanied by fragments of thick-branched, columnar-like Goniopora and Actinacis and also by some massive corals, especially Astreopora and subordinately faviids (i.e., Antiguastrea). Fragmentation is high and also affects massive growth forms (Fig. 9A); abrasion is moderately developed. Encrustation as thin $(<1 \mathrm{~mm})$ coralline algal crusts is moderate. Bioerosion is high and represented by Gastrochoenolites and Trypanites with subordinate Entobia. Boring traces are usually broken by subsequent fragmentation and topped by encrustations when present. Crusts are homogenously developed around coral fragments, thus encrustation is the last process affecting the coral remains on the sediment surface.

Distribution.--Restricted to the lower-middle part of the Dupeljnik-6 section (Fig. 7).

Interpretation.-Although a certain degree of reworking can be inferred by high fragmentation rates, coral rubble was deposited nearly in situ as supported by relatively moderate abrasion rates. High degrees of fragmentation can be explained by intense bioerosion, which weakened the fine-branching morphotypes (Pleydell and Jones, 1988). Massive growth forms are also highly susceptible to bioerosion as they offer attractive substrates for bioeroders (Perry, 1996; Pandolfi and Greenstein, 1997). 

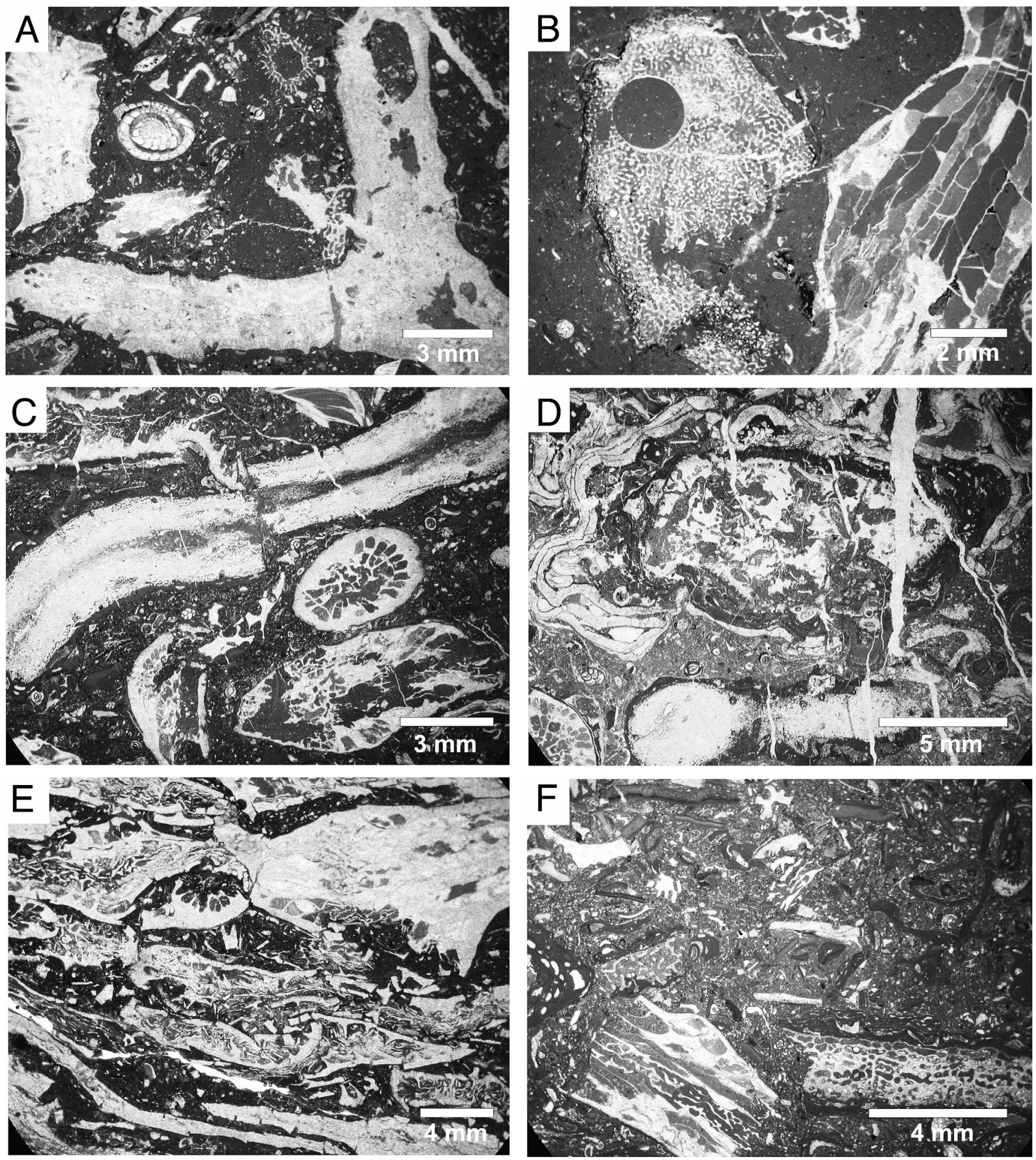

FIGURE 8-Coral microtaphofacies. A) Microtaphofacies (MTF) 1. SLO94-015. Abraded branched Stylophora with a smaller fragment in the upper left (i.e., moderate fragmentation). Note the absence of encrustation. B) MTF 1. SLO94-027A. Fragment of Actinacis bored by Lithophaga. C) MTF 2. KO-21. Adjacent fragments clearly belong to the same branch of hydrozoan (i.e., low fragmentation). The thin algal crust is broken together with its hydrozoan substrate. D) MTF 2. KO-15. Thick multi-taxon encrustation including Polystrata alba (calcareous alga) around a fragment of Acropora. Trypanites traces on the coral are visible. E) MTF 3. KO-17. Unidentified highly fragmented and compressed corals, lying parallel to bedding. F) MTF 4. DU3-22. Highly fragmented unidentified coral remains within a coralline algal-rich rudstone.

A sheltered low-hydrodynamic setting is inferred for MTF 5. The dominance of traces referred to boring bivalves (Gastrochoenolites) and worms (Trypanites) over those of boring sponges (Entobia) has been reported as a possible indicator of high sedimentation, turbid environments (Macdonald and Perry, 2003; Smithers and Larcombe, 2003). Massive corals may indicate a setting where turbidity is more important that sediment accumulation in determining coral presence. Massive corals are more dependent on active sediment rejection than the passive sediment removal utilized by branching corals (Bak and Elgershuizen, 1976; Rogers, 1983). This mechanism is an effective process for removing fine-grained sediments (Stafford-Smith, 1993) which are prevalent as suspended particles especially in low-turbulent 
settings. The high rates of boring traces furthermore suggest high nutrient availability. Studies from the Great Barrier Reef demonstrate that a shift in macroboring communities from sponge to bivalve dominance is typical of nearshore fringing reefs within turbid and nutrient-rich environments (Sammarco and Risk, 1990; Risk et al., 1995; Schönberg et al., 1997).

A quiet setting is reconstructed for MTF 5, likely more distal than those inferred for the other nearly in situ MTFs 1 and 2. Suspended mud could possibly serve as a food source for macroborers and even for heterotrophic corals (Anthony and Fabricius, 2000). Low water transparency could be disadvantageous for calcareous encrusters (Perry and Smithers, 2006), thus explaining the limited development of complex and thick encrustations on corals.

\section{DISCUSSION}

Temporal Sequence and Mutual Influence of Taphonomic Processes

Determination of the temporal sequence of taphonomic features can be used to establish whether coral fragmentation occurred before or after bioinfestation. This distinction is needed in order to identify bioerosion-induced fragmentation as interpreted for MTFs 1 and 5. The identification of bioerosion as present prior to encrustation is relatively easy to determine if the non-bored crusts extend over and seal bored substrates. This feature has been assessed for most of the microtaphofacies (except MTF 3) allowing encrustation to be recognized as the last taphonomic process to occur before burial. The lack of truncated traces within a facies displaying a considerable degree of bioerosion may demonstrate that it occurred after fragmentation. This assumption, however, must be evaluated with caution, especially when bioerosion is dominated by smaller traces such Trypanites. Inferring post-fragmentation encrustation is clearly denoted by crusts covering the broken boundaries of coral fragments (MTF 4).

The close relationship between abrasion and bioerosion may reflect high rates of biological activity. Protection offered by encrustation against pervasive fragmentation and bioerosion provided by strengthening and coating the coral skeletons can be assumed for MTF 2. In turn, highly fragmented coral rubble is likely to be preferentially infested by encrusters (Nebelsick et al., 2011b) and borers (Perry, 1996). Abrasion seems to be positively correlated with fragmentation, which is to be expected since physical abrasion and fragmentation are related to higher water energy rates. Finally, high degrees of fragmentation can ultimately exacerbate the recognition of previous taphonomic processes (MTF 3). The temporal sequences of taphonomic processes inferred for the analyzed microtaphofacies and their possible environmental significance are illustrated in Figure 10.

\section{Microtaphofacies (MTFs) and Sedimentary Input}

Stress due to sedimentary input is known to play a major role in determining coral diversity, density, health, vulnerability, and duration of coral communities. This aspect is assessed for the coral assemblages of Gornji Grad Beds, where coral diversity is kept at low levels and a general shift to sediment-resistant genera is displayed. The influence of sedimentary input resulting in water turbidity or sediment accumulation can be evaluated through a combined analysis of dominant coral genera, growth forms, and taphonomic features. The most significant information concerning sedimentary input is mainly obtained from the parautochthonous MTFs, namely MTFs 1, 2, and 5.

Sediment accumulation may cause the dominance of coral branching morphotypes that are adapted to passive removal of sediment (Sanders and Baron-Szabo, 2005), and also contribute to low levels of encrustation and bioerosion on coral remains (Scoffin, 1992). A high amount of sediment accumulation can thus be inferred for MTFs 1 and 2, clearly dominated by typically fast-growing branching corals
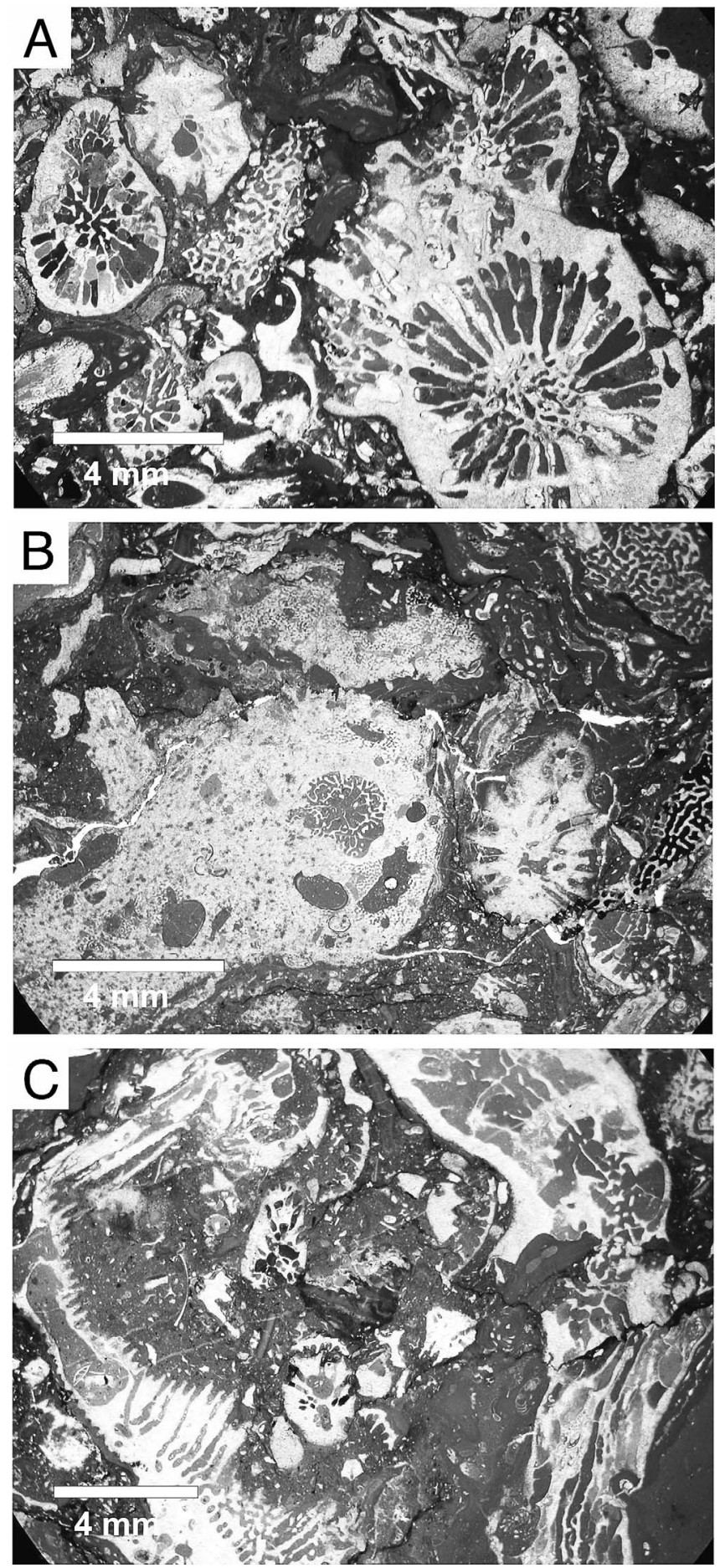

FIGURE 9-Coral microtaphofacies (MTF). A) MTF 5. DU6-7. A fragmented, massive faviid-like coral (i.e., high fragmentation). Its outer wall is also bored (Trypanites). B) MTF 5. DU6-1. Coral fragments: the abraded and bored (Gastrochoenolites) larger fragment is probably a massive Astreopora. Coral fragments are also sparsely encrusted by coralline algae. C) MTF 5. DU6-1. Highly bored and fragmented unidentified corals. Most boring traces are referred to Trypanites.

(including some pioneer genera such as Stylophora and Actinacis) and could also be responsible for the much lower intensity and complexity of encrustation in MTF 1 with respect to MTF 2.

Fine-branching Stylophora and Acropora, which dominate MTFs 1 and 2, are known to feed largely autotrophically and hence to be generally light dependent, but large polyped, massive corals can 


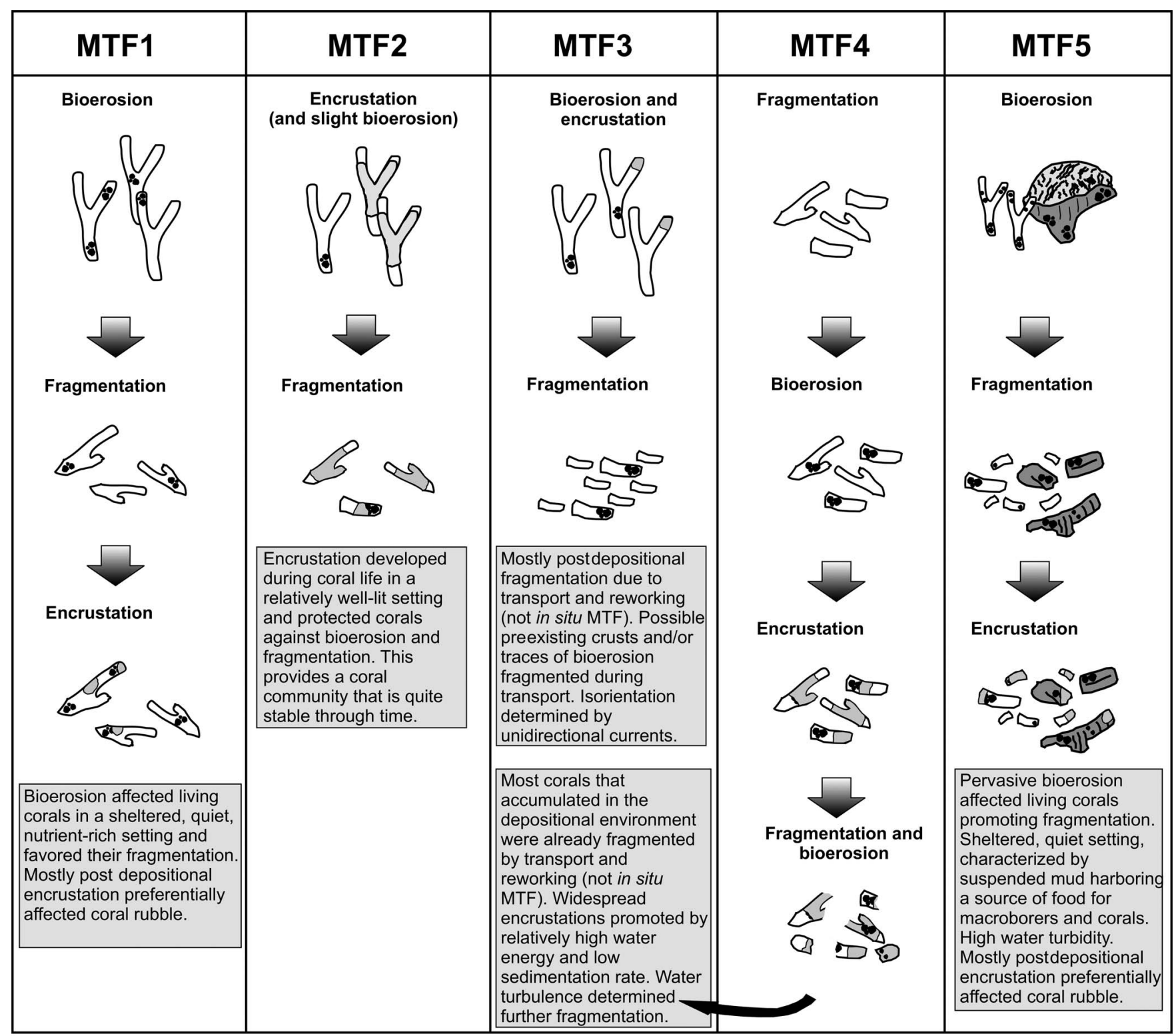

FIGURE 10-Temporal sequences of taphonomic processes characterizing the MTFs and their environmental significance.

ultimately cope well with low water transparencies as they cover large parts of their nutritional needs by heterotrophy (references in Sanders and Baron-Szabo, 2005). The occurrence of massive growth forms assessed for MTF 5 may thus reflect a setting affected by water turbidity determined by fine-grained sediment suspension. This interpretation is corroborated by the particularly severe bioerosion assessed for MTF 5, which could be promoted by a relatively long surface residence time of coral remains. Lastly, the higher relative abundance of boring bivalves and worms as opposed to sponges within the macroboring community may be regarded as indicative of a setting where suspended sediment frequently occurred throughout the water column (Macdonald and Perry, 2003; Smithers and Larcombe, 2003).

High sedimentary input can ultimately restrict the development of reef frameworks (Macdonald and Perry, 2003) or determine their destruction through the intensification of bioerosion due to high nutrient supply discharged by sedimentary input from the coast (Hallock, 1988; Edinger et al., 2000). This aspect was assessed for the coral assemblages of Gornji Grad Beds, which actually did not form frameworks (see below) and were often reduced to coral rubble.
Depositional Model of the Gornji Grad Coral Assemblages

According to the depositional model proposed for the Gornji Grad carbonates by Nebelsick et al. (2000), a nearshore fully marine environment within the photic zone has been reconstructed for all the facies, including the coral facies. The present study has shown the potential of a non-conventional approach based on microtaphofacies analysis to investigate the coral facies in more detail. This approach allows different subenvironments and strategies of coral colonization to be distinguished.

A model has been developed (Fig. 11) showing the time-transgressive deposition of the investigated coral-rich succession during the early Oligocene and in particular, the distribution of MTFs in time and space and their relationship to the major environmental parameters. At time T1, coral colonization was only possible in the area of DU sections. Proximal marine and/or continental sedimentation occurred at the same time at other localities. Corals did not form true reefs, but rather isolated and patchy clusters sensu Riding (2002) (MTF 5). Clusters were composed of different coral growth forms even if dominated by thick- 


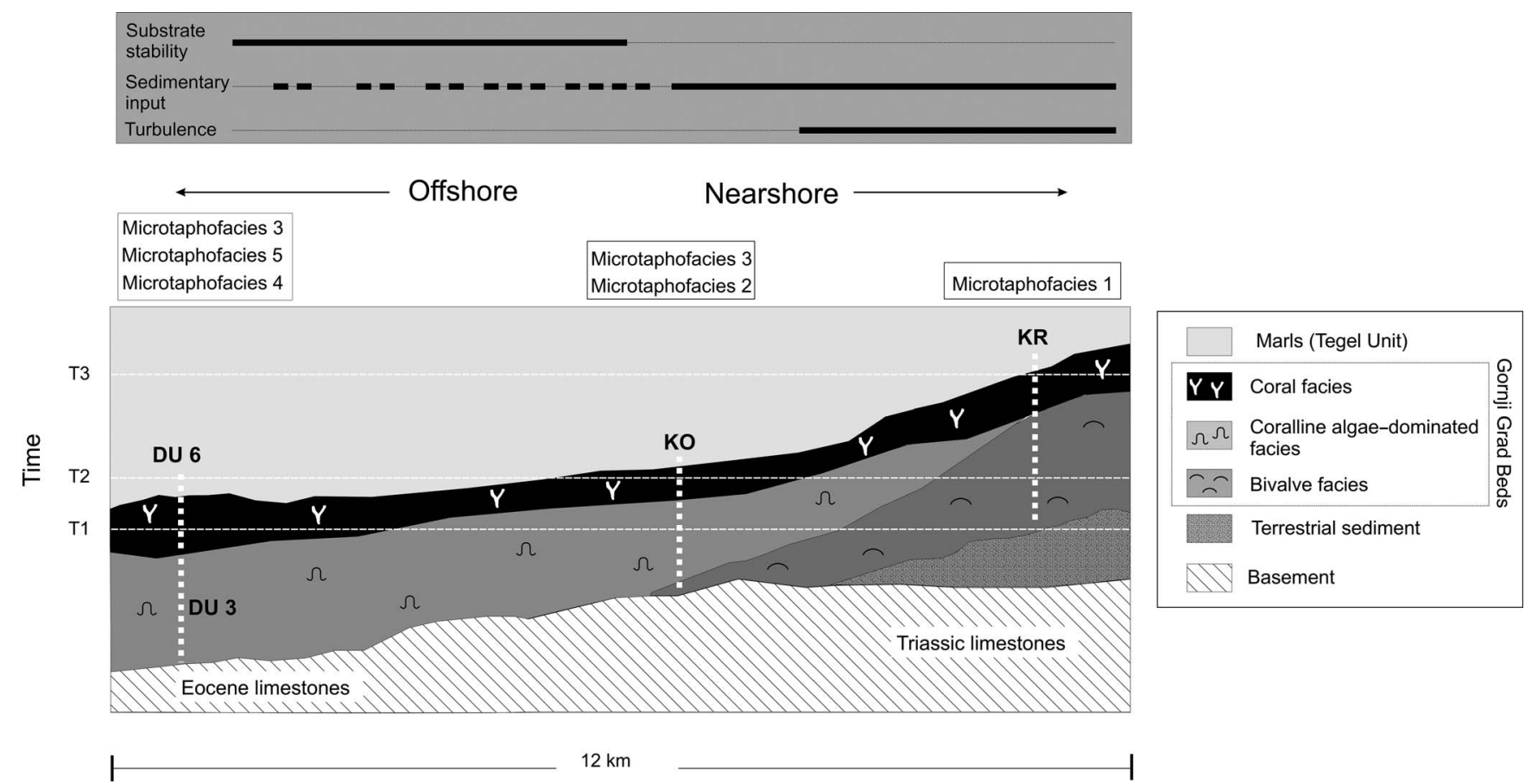

FIGURE 11-Depositional model of the coral facies in the Lower Oligocene Gornji Grad Beds. The distribution of MTFs in space and time is illustrated. The upper part of the diagram depicts the change of the main environmental controlling factors throughout the investigated stratigraphic sections and the inferred prevailing nature of nearshore versus offshore deposits.

branched Actinacis and Goniopora, which are considered to be genera well adapted to mud-dominated settings. Higher water turbidity resulted not only from the large amount of suspended carbonate mud, but also from a possible higher concentration of nutrients. Nutrient supply promoted a flourishing of a bioeroding community shifting toward a Lithophaga-dominated association. High rates of bioerosion strongly contributed to rubble formation by weakening living corals and/or intensifying the breakage of coral remains after death. Coral debris could occasionally be transported laterally by currents and the highly reworked and encrusted MTF 4 may represent this depositional product (Riegl and Piller, 2000). Dead coral remains were also occasionally transported into deeper waters (MTF 3). Episodes with higher turbidity and/or sediment accumulation were probably responsible for coral demise and subsequent sedimentation of marly layers devoid of macrofossils.

At time T2 and T3, marine transgression permanently prevented coral colonization first in the DU localities and afterward in $\mathrm{KO}$ as well, leading to deposition of the deeper marine sediments of the Tegel unit. At time T3, coral colonization was possible only in KR. MTFs 1 and 2 represent episodes of coral colonization at different times (T2 and T3, respectively). In these cases corals are interpreted to occupy small and patchy areas, not far from the coast (likely in depths of a few meters) and to represent relatively short-living coral communities where only a few fast-growing pioneer genera such as Stylophora could survive. Original associations are inferred to be represented by widelyspaced oligotypic coral carpets sensu Riegl and Piller (1999) dominated by finely branching corals. Coral carpets are reported in the literature to contain numerous sediment-infilled cavities: depositional products will frequently result in rudstones composed predominantly of coral rubble included in packstones or wackestones (Riegl and Piller, 1999). Coral communities had to cope with the stress caused by periodic episodes of sediment suspension and/or accumulation. The allochthonous deposits of MTF 3 recognized at the top of KO section have been interpreted as coral remains transported into deeper waters, analogous to what is inferred for the DU6 section.

\section{CONCLUSIONS}

The depositional history and environment of the coral-rich facies in the lower Oligocene Gornji Grad Beds of Slovenia have been reconstructed through a detailed microtaphofacies study, emphasizing the potentiality of taphonomic features as paleoenvironmental indicators of fossil reefs, in particular those thriving within turbid-water conditions and affected by sedimentary input. Our main findings can be summarized as follows:

1. Five different microtaphofacies (MTFs) were distinguished and interpreted based on dominant coral taxa and their growth forms, and according to the presence, rates, and temporal succession of fragmentation, abrasion, encrustation, and bioerosion. Bioinfestation is further differentiated based on types of bioerosion traces and the taxonomy and thickness of encrusting organisms.

2. Taphonomic signatures such as fragmentation levels and abrasion rates allowed us to distinguish parautochthonous (MTFs 1,2,5) and allochthonous (MTFs 3, 4) assemblages.

3. The influence of sedimentary input was estimated for the parautochthonous assemblages. The dominance of mostly delicate coral branching morphotypes adapted to passive removal of sediment, together with low levels of bioerosion and encrustation, are good indicators of sediment accumulation and relatively high sedimentation rates. Turbid-water conditions with suspension of fine-grained sediment were recognized if the surface residence time of coral remains is relatively long, allowing for the development of intense bioerosion, especially that of boring bivalves like Lithophaga, and complex and thick encrustations.

4. These coral assemblages did not represent true reefs but rather cluster reefs sensu Riding (2002) or coral carpets sensu Riegl and Piller (1999), dominated by a few sediment-resistant (Actinacis, Caulastrea) and/or fast-growing pioneer genera (Stylophora) within a muddominated setting.

5. Our results clearly show that coral rubble can also be formed in these relatively low-energy settings when bioerosion strongly affects 
delicate-branching corals thus weakening their skeletons and leading to bioerosion-induced fragmentation.

\section{ACKNOWLEDGMENTS}

We thank two anonymous reviewers for their very helpful comments and suggestions. Initial studies on microfacies were supported by grants from the German Science Foundation (DFG, Deutsche Forschungsgemeinschaft) to James H. Nebelsick. Material was originally sampled under the auspices of a bilateral project between the University of Tübingen and Ljubljana University. Giulia Silvestri was supported by the International Association of Sedimentologists (IAS) 2008 Postgraduate Grant.

\section{REFERENCES}

Anthony, K.R.N., and Fabricius, K.E., 2000, Shifting roles of heterotrophy and autotrophy in coral energetics under varying turbidity: Journal of Experimental Marine Biology and Ecology, v. 252, p. 221-253.

BAK, R.P.M., and ElgERShuIZEN, J.H.B.W., 1976, Pattern of oil-sediment rejection in corals: Marine Biology, v. 37, p. 105-113.

Barta-Calmus, S., 1973, Révision de Collections de Madréporaires Provenants du Nummulitique du sud-est de la France, de l'Italie et de la Yougoslavie Septentrionales: Unpublished Thèse de Doctorat d'Etat es Sciences Naturelles, C.N.R.S, Paris, 695 p.

Bassi, D., and Nebelsick, J.H., 2000, Calcareous algae from the lower Oligocene Gornji Grad Limestones of northern Slovenia: Rivista Italiana di Paleontologia e Stratigrafia, v. 106, p. 99-122.

Bertling, M., 2000, Coral reef bioerosion in times of crises: The Late Triassic/Early Jurassic example: Proceedings, Ninth International Coral Reef Symposium, Bali, 23-27 Oct. 2000, v. 1, p. 283-288.

Blanchon, P., and Perry, C.T., 2004, Taphonomic differentiation of Acropora palmata facies in cores from Campeche Bank reefs, Gulf of Mexico: Sedimentology, v. 52, p. 53-76.

Bosellini, F.R., and Perrin, C., 2008, Estimating Mediterranean Oligocene-Miocene sea-surface temperatures: An approach based on coral taxonomic richness: Palaeogeography, Palaeoclimatology, Palaeoecology, v. 258, p. 71-88.

Bosellini, F.R., and Stemann, T.A., 1996, Autoecological significance of growth form in the scleractinian coral Actinacis rollei Reuss (Oligocene, Lessini Mountains, Northern Italy), in Cherchi A., ed., Autoecology of Selected Fossil Organisms: Achievements and Problems: Bollettino della Società Paleontologica Italiana, Modena, Volume Speciale 3, p. 31-43.

Boseluini, F.R., and Trevisani, E., 1992, Coral facies and cyclicity in the Castelgomberto Limestone (Early Oligocene, Eastern Lessini Mountains, Northern Italy): Rivista Italiana di Paleontologia e Stratigrafia, v. 98, p. 339-352.

Brachert, T.C., Betzler, C., Braga, J.C., and Martin, J.M., 1998, Microtaphofacies of a warm-temperate carbonate ramp (uppermost Tortonian/lowermost Messinian, Southern Spain): PALAIOS, v. 13, p. 459-475.

Braga, J.C., Martin, J.M., and Alcala, B., 1990, Coral reefs in coarse-terrigenous sedimentary environments (Upper Tortonian, Granada Basin, southern Spain): Sedimentary Geology, v. 66, p. 135-150.

Bricl, B., and PAvŠIČ, J., 1991, Pogostnost nanoplanktona v oligocenski morski glini v Sloveniji (Frequency of nannoplankton in Oligocene marine clay in Slovenia): Razprave IV. razreda SAZU (Slovenske Akademije Znanosti in Umetnosti), v. 32, p. $154-173$.

Bromley, R.C., 1972, On some ichnotaxa in hard substrates, with a redefinition of Trypanites Mägdefrau: Paläontologische Zeitschrift, v. 46, p. 93-98.

Bromley, R.C., and D'Alessandro, A., 1984, The ichnogenus Entobia from the Miocene, Pliocene and Pleistocene of southern Italy: Rivista Italiana di Paleontologia e Stratigrafia, v. 90, p. 227-296.

Bromley, R.C., and D'Alessandro, A., 1989, Ichnological study of shallow marine endolithic sponges from the Italian coast: Rivista Italiana di Paleontologia e Stratigrafia, v. 95 , p. 279-314.

Budd, A.F., 2000, Diversity and extinction in the Cenozoic history of Caribbean reefs: Coral Reefs, v. 19, p. 25-35.

Cahuzac, B., and Poignant, A., 1997, Essai de biozonation de l'Oligo-Miocène dans les bassins européens à l'aide des grands foraminfères néritiques: Bulletin de la Société Géologique de France, v. 168, p. 155-169.

Cimerman, F., 1979, Oligocene beds in Slovenia, in Drobne, K., ed., Guidebook, 16th European Micropaleontological Colloquium (Zagreb-Bled, Yugoslavia, 1979): Croatian Geological Society and Slovenian Geological Society, Ljubljana, p. 65 70 .
Drobne, K., Pavlovec, R., Drobne, F., Cimerman, F., and Sikić, L., 1985, Some larger foraminifera from the Upper Eocene and basal Oligocene beds in North Slovenia: Geološki Glasnik (Bulletin Géologique), v. 28, p. 77-117.

Dryer, S., and Logan, A., 1978, Holocene reefs and sediments of Castle Harbour, Bermuda: Journal of Marine Research, v. 36, p. 399-425.

Dunham, R.J., 1962, Classification of carbonate rocks according to their depositional texture, in Ham, W.E., ed., Classification of Carbonate Rocks: American Association of Petroleum Geologists Memoir, v. 1, p. 108-121.

Dupraz, C., and Strasser, A., 2002, Nutritional modes in coral-microbialite reefs (Jurassic, Oxfordian, Switzerland): Evolution of trophic structure as a response to environmental change: PALAIOS, v. 17, p. 449-471.

EDINGER, E.N., and Risk, M.J., 1994, Oligocene-Miocene extinction and geographic restriction of Caribbean corals: Roles of turbidity, temperature and nutrients: PALAIOS, v. 9, p. 576-598.

Edinger, E.N., Limnon, G. V., Jamaluddin, J., Heikoop, W., and Risk, M.J., 2000, Normal coral growth rates on dying reefs: Are coral growth rates indicators of reef health?: Marine Pollution Bulletin, v. 40, p. 404- 425.

Embry, A.F., and Klovan, J.E., 1971, A late Devonian reef tract of northeastern Banks Islands. Northwest Territories: Bulletin of the Canadian Petroleum Geology, v. 19, p. 730-781.

FLÜGEL, E., 2004, Microfacies of Carbonate Rocks: Springer-Verlag, Germany, 976 p. Frost, S.H., 1977, Oligocene reef coral biogeography. Caribbean and Western Tethys: Mémoires du Bureau de Recherches Géologiques et Minières, v. 89, p. 342 352.

Frost, S.H., 1981, Oligocene reef coral biofacies of the Vicentin, northeast Italy, in Toomey, T.F., ed., European Fossil Reef Models: Society of Economic Paleontologists and Mineralogists (SEPM) Special Publication, Tulsa, Oklahoma, v. 30 , p. $483-539$.

Greenstein, B.J., 2007. Taphonomy: Detecting critical events in fossil reef coral assemblages, in Aronson, R.B., ed., Geological Approaches to Coral Reef Ecology: Springer, New York, p. 31-60.

Greenstein, B.J., and Pandolfi, J.M., 2003, Taphonomic alteration of reef corals: Effects of reef environment and coral growth form II: The Florida Keys: PALAIOS, v. 18, p. 495-509.

HALloCK, P., 1988, The role of nutrient availability in bioerosion: Consequences to carbonate buildups: Palaeogeography, Palaeoclimatology, Palaeoecology, v. 63, p. 275-291.

Hallock, P., 2005, Global change and modern coral reefs: New opportunities to understand shallow-water carbonate depositional processes: Sedimentary Geology, v. 175 , p. $19-33$.

Hallock, P., and Schlager, W., 1986, Nutrient excess and the demise of coral reefs and carbonate platforms: PALAIOS, v. 1, p. 389-398.

Hanfland, C., LÄufer, A.L., Nebelsick, J.H., and Mosbrugger, V., 2004, The Smrekovec Tertiary and related volcanism (Slovenia): Sedimentology, geochemistry, and tectonic evolution: Neues Jahrbuch für Geologie und Paläontologie, Abhandlungen, v. 232, p. 77-125.

Hemleben, C., 1964, Geologisch-paläontologische Untersuchung im Gebiet zwischen Gornji Grad (Oberburg) and Nova Štifta (Neustift) in Nordslowenien/Jugoslawien: Unpublished diploma thesis, University München, München, Germany, 109 p.

Hubbard, D.K., Miller, A.I., and Scaturo, D., 1990, Production and cycling of calcium carbonate in a shelf-edge reef system (St. Croix, U.S. Virgin Islands): Applications to the nature of reef systems in the fossil record: Journal of Sedimentary Petrology, v. 60, p. 335-360.

Hubbard, D.K., Gill, I.P., and Burke, R.B., 2001, The role of framework in modern reefs and its application to ancient systems, in Stanley, G.D., Jr., ed., The History and Sedimentology of Ancient Reef Systems: Topics in Geobiology, vol. 17, Kluwer/Plenum, New York., p. 351-386.

Hutchings, P.A., 1986, Biological destruction of coral reefs: A review: Coral Reefs, v. 4, p. $239-242$.

Jelen, M., Lapanje, V., and Pavšič, J., 1980, Nanoplankton in dinoflagelati iz oligocenskih plasti na Homu pri Radmirju (Nannoplankton and dinoflagellates from the Oligocene beds of Hom): Geologija, v. 23, no. 2, p. 177-188.

Johnson, K.G., JACKson, J.B.C., and Budd, A.F., 2008, Caribbean reef development was independent of coral diversity over 28 million years: Science, v. 319, p. $1521-$ 1523 .

Kelly, S.R.A., and Bromley, R.G., 1984, Ichnological nomenclature of clavate borings: Palaeontology, v. 27, p. 793-807.

Klaus, J.S., Lutz, B.P., Budd, A.F., McNeill, D.F., and Ishman, S.E., 2011, Rise and fall of Pliocene free-living corals in the Caribbean and western Atlantic: Geology, v. 39, p. 375-378.

Lokier, S.W., Wilson, M.E.J., and Burton, L.M., 2009, Marine biota response to clastic sediment influx: A quantitative approach: Palaeogeography, Palaeoclimatology, Palaeoecology, v. 281, p. 25-42.

Macdonald, I.A., and Perry, C.T., 2003, Biological degradation of coral framework in a turbid lagoon environment, Discovery Bay, north Jamaica: Coral Reefs, v. 22, p. $523-535$ 
Morsilli, M., Bosellini, F., Pomar, L., Hallock, P., Aurell M., and Papazzoni, C.A., 2011, Mesophotic coral buildups in a prodelta setting (late Eocene, southern Pyrenees, Spain): A mixed carbonate-siliciclastic system: Sedimentology, [EARLY VIEW], 29 p., doi: 10.1111/j.1365-3091.2011.01275.x.

Nebelsick, J.H., and BASSI, D., 2000, Diversity, growth form and taphonomy: Factors controlling the fabric of coralline algae dominated shelf carbonates, in Insalaco, E., Skelton, P.W., and Palmer, T.J., eds., Carbonate Platform Systems: Components and Interactions: Geological Society, London, Special Publication, v. 178, p. $89-107$

Nebelsick, J.H., and Kiene, W.E., 1997, Taphonomy: An ecological tool for studies of living and fossil reefs, in Lessios, H.A., and Macintyre, I.G., eds., Proceedings of the Eighth International Coral Reef Symposium (Panama City, 1996): Smithsonian Tropical Research Institute, Panama, v. 2, p. 1787-1788.

Nebelsick, J.H., Drobne, K., and Bassi, D., 2000, Microfacies analysis and palaeoenvironmental interpretation of Lower Oligocene, shallow water carbonates (Gornji Grad Beds, Slovenia): Facies, v. 43, p. 157-176.

Nebelsick, J.H., Bassi, D., and Rasser, M.W., 2011a, Microtaphofacies: exploring the potential for taphonomic analysis in carbonates, in Allison, P.A. and Bottjer, D.J., eds., Taphonomy: Process and Bias Through Time, Second Edition: Springer, Dordrecht, The Netherlands, p. 587-621.

Nebelsick, J.H., Bassi, D., and Rasser, M.W., 2011b, Cryptic relicts from the past: Palaeoecology and taphonomy of encrusting thecideid brachiopods in Paleogene carbonates: Annalen des Naturhistorischen Museums in Wien A, v. 113, p. 532 542.

Olóriz, F., Reolid, M., and Rodríguez-Tovar, F.J., 2004, Taphonomy of ammonite assemblages from the Middle-Upper Oxfordian (Transversarium?-Bifurcatus Zones) in the Internal Prebetic (Betic Cordillera, southern Spain): Taphonomic populations and taphofacies to support ecostratigraphic interpretations: Rivista Italiana di Paleontologia e Stratigrafia, v. 110, p. 239-248.

Pandolfi, J.M., and Greenstein, B.J., 1997, Taphonomic alteration of reef corals: Effects of reef environment and coral growth form I: The Great Barrier Reef: PALAIOS, v. 12, p. 27-42.

Perrin, C., 2002, Tertiary: The emergence of modern reef ecosystems, in Kiessling, W., Flügel, E., and Golonka, J., eds., Phanerozoic Reef Patterns: SEPM (Society for Sedimentary Geology) Special Publication, v. 72, p. 587-621.

Perry, C.T., 1996, Distribution and abundance of macroborers in an upper Miocene reef system, Mallorca, Spain: Implications for reef development and framework destruction: PALAIOS, v. 11, p. 40-56.

Perry, C.T., 2005, Structure and development of detrital reef deposits in turbid nearshore environments, Inhaca Island, Mozambique: Marine Geology, v. 214, p. $143-161$.

Perry, C.T., and Bertling, M., 2000, Spatial and temporal patterns of macroboring within Mesozoic and Cenozoic coral reef systems, in Insalaco, E., Skelton, P.W., and Palmer, T.J., eds., Carbonate Platform Systems: Components and Interactions: Geological Society, London, Special Publication, v. 178, p. 33-50.

Perry, C.T., and Hepburn, L.J., 2008, Syn-depositional alteration of coral reef framework through bioerosion, encrustation and cementation: Taphonomic signatures of reef accretion and reef depositional events: Earth-Science Reviews, v. 86, p. $106-144$

Perry, C.T., and Smithers, S.G., 2006, Taphonomic signatures of turbid-zone reef development: Examples from Paluma Shoals and Lugger Shoal, inshore central Great Barrier Reef, Australia: Palaeogeography, Palaeoclimatology, Palaeoecology, v. 242, p. 1-20.

Pleydell, S. M., and Jones, B., 1988, Boring of various faunal elements in the Oligocene-Miocene Bluff Formation of Grand Cayman, British West Indies: Journal of Paleontology, v. 62, n. 3, p. 348-367.

PotTs, D.C., and JACoBs, I.R., 2000, Evolution of reef-building scleractinian corals in turbid environments: A paleo-ecological hypothesis, in Moosa, M.K., Soemodihardjo, S., Soegiarto, A., Romimohtarto, K., Nontji, A., Soekarno, A., and Suharsono, A., eds., Proceedings of the Ninth International Coral Reef Symposium (Bali, 2000): v. 1, p. 249-254.

Reolid, M., and Gaillard, C., 2007, Microfacies, microtaphonomic traits and foraminiferal assemblages from Upper Jurassic spongiolithic limestones (External Prebetic, southern Spain): Facies, v. 53, p. 97-112.
Reolid, M., Gaillard, C., and Lathuilière, B., 2007, Microfacies, microtaphonomic traits and foraminiferal assemblages from Upper Jurassic oolitic-coral limestones: Stratigraphic fluctuations in a shallowing-upward sequence (French Jura, Middle Oxfordian): Facies, v. 53, p. 553-574.

Reuss, A.E., 1864, Die fossilen Foraminifera, Anthozoen, und Bryozoen von Oberburg in der Steiermark: Denkschriften der Kaiserlichen Akademie der Wissenshaften, Mathematisch-Naturwissenschaftliche Classe, v. 23, p. 1-36.

RIDING, R., 2002, Structure and composition of organic reefs and carbonate mud mounds: Concepts and categories: Earth-Science Reviews, v. 58, p. 163-231.

Riegl, B., and PIller, W.E., 1999, Coral frameworks revisited: Reefs and coral carpets in the northern Red Sea: Coral Reefs, v. 18, p. 241-253.

Riegl, B., and Piller, W.E., 2000, Biostromal coral facies. A Miocene example from the Leitha Limestone (Austria) and its actualistic interpretation: PALAIOS, v. 5, p. 399-413.

Risk, M.J., Sammarco, P.W., and Edinger, E.N., 1995, Bioerosion in Acropora across the continental shelf of the Great Barrier Reef: Coral Reefs, v. 14, p. 79-86.

Rogers, C.S., 1983, Sublethal and lethal effects of sediments applied to common Caribbean reef corals in the field: Marine Pollution Bulletin, v. 14, p. 378-382.

Sammarco, P.W., and Risk, M.J., 1990, Large-scale patterns in internal bioerosion of Porites: Cross continental shelf trends on the Great Barrier Reef: Marine Ecology Progress Series, v. 59, p. 145-156.

SANDERS, D., 1999, Shell disintegration and taphonomic loss in rudist biostromes: Lethaia, v. 32, p. 101-112.

Sanders, D., 2003, Syndepositional dissolution of calcium carbonate in neritic carbonate environments: Geological recognition, processes, potential significance: Journal of African Earth Sciences, v. 36, p. 99-134.

SAnders, D., and BARON-SzaBo, R.C., 2005, Scleractinian assemblages under sediment input: Their characteristics and relation to the nutrient input concept: Palaeogeography, Palaeoclimatology, Palaeoecology, v. 216, p. 139-181.

Sanders, D., and Krainer, K., 2005, Taphonomy of Early Permian benthic assemblages (Carnic Alps, Austria). Carbonate dissolution versus biogenic carbonate precipitation: Facies, v. 51, p. 522-540.

SCHLAGER, W., 2000, Sedimentation rates and growth potential of tropical, cool water and mud mound carbonate factories, in Insalaco, E., Skelton, P.W., and Palmer, T.J., eds., Carbonate Platform Systems: Components and Interactions: Geological Society, London, Special Publication, v. 178, p. 217-227.

Schlager, W., 2003, Benthic carbonate factories of the Phanerozoic: International Journal of Earth Sciences, v. 92, p. 445-464.

Schmiedl, G., Scherbacher, M., Bruch, A.A., Jelen, B., Nebelsick, J.H., Hemleben, C., Mosbrugger, V., and Rifelj, H., 2002, Paleoenvironmental evolution of the Paratethys in the Slovenian Basin during the Late Paleogene: International Journal of Earth Sciences, v. 91, p. 123-132.

Schönberg, C.H.L., Wilkinson, C.R., and Hoppe, K.N., 1997, Coral skeleta destruction: Boring on the Great Barrier Reef, in The Great Barrier Reef: Science, Use and Management: A National Conference, Proceedings (Townsville, Australia, 1996): Great Barrier Reef Marine Park Authority, v. 2, p. 67-71.

Scoffin, T.P, 1992, Taphonomy of coral reefs: A review: Coral Reefs, v. 11, p. 57-77.

Scotт, P.J.B., 1988, Distribution, habitat and morphology of the Caribbean coraland rock-boring bivalve, Lithophaga bisulcata (d'Orbigny) (Mytilidae: Lithophaginae): Journal of Molluscan Studies, v. 54, p. 83-95

Smithers, S. G., and Larcombe, P., 2003, Holocene initiation and growth of a nearshore turbid-zone coral reef: Paluma Shoals, central Great Barrier Reef, Australia: Coral Reefs, v. 22, p. 499-505.

Stafford-Smith, M.G., 1993, Sediment-rejection efficiency of 22 species of Australian scleractinian corals: Marine Biology, v. 115, p. 229-243.

Vogel, K., 1993, Bioeroders in fossil reefs: Facies, v. 28, p. 109-114.

WiLson, M.E.J., 2005, Equatorial delta-front patch reef development during the Neogene, Borneo: Journal of Sedimentary Research, v. 75, p. 116-134.

Wood, R., 1993, Nutrients, predation and the history of reef building: PALAIOS, v. 8 , p. $526-543$.

Woolfe, K.J., and Larcombe, P., 1999, Terrigenous sedimentation and coral reef growth: A conceptual framework: Marine Geology, v. 155, p. 331-345.

ACCEPTED OCTOBER 4, 2011 